\title{
Localization of diacylglycerol lipase alpha and monoacylglycerol lipase during postnatal development of the rat retina
}

\author{
Bruno Cécyre 1,2, Marjorie Monette ${ }^{1}$, Liza Beudjekian ${ }^{1}$, Christian Casanova $^{2}$ and Jean-François Bouchard ${ }^{1}$ * \\ ${ }^{1}$ Laboratoire de Neuropharmacologie, École d'Optométrie, Université de Montréal, Montréal, QC, Canada \\ ${ }^{2}$ Laboratoire des Neurosciences de la vision, École d'Optométrie, Université de Montréal, Montréal, QC, Canada
}

Edited by:

Nicolás Cuenca, University of

Alicante, Spain

\section{Reviewed by:}

William K. Stell, University of

Calgary Faculty of Medicine,

Canada

Ismael Galve-Roperh, Complutense

University, Spain

${ }^{*}$ Correspondence:

Jean-François Bouchard, Laboratoire de Neuropharmacologie, École d'Optométrie, Université de

Montréal, C.P. 6128 Succursale

Centre-Ville, Montréal, H3C 3J7 OC,

Canada

e-mail: jean-francois.bouchard@

umontreal.ca
In recent decades, there has been increased interest in the physiological roles of the endocannabinoid (eCB) system and its receptors, the cannabinoid receptor types 1 (CB1R) and 2 (CB2R). Exposure to cannabinoids during development results in neurofunctional alterations, which implies that the eCB system is involved in the developmental processes of the brain. Because of their lipophilic nature, eCBs are synthesized on demand and are not stored in vesicles. Consequently, the enzymes responsible for their synthesis and degradation are key regulators of their physiological actions. Therefore, knowing the localization of these enzymes during development is crucial for a better understanding of the role played by eCBs during the formation of the central nervous system. In this study, we investigated the developmental protein localization of the synthesizing and catabolic enzymes of the principal eCB, 2-arachidonoylglycerol (2-AG) in the retinas of young and adult rats. The distribution of the enzymes responsible for the synthesis (DAGL $\alpha$ ) and the degradation (MAGL) of 2-AG was determined for every retinal cell type from birth to adulthood. Our results indicate that DAGL $\alpha$ is present early in postnatal development. It is highly expressed in photoreceptor, horizontal, amacrine, and ganglion cells. MAGL appears later during the development of the retina and its presence is limited to amacrine and Müller cells. Overall, these results suggest that 2-AG is strongly present in early retinal development and might be involved in the regulation of the structural and functional maturation of the retina.

Keywords: endocannabinoid system, 2-arachidonoylglycerol, cannabinoid, immunohistochemistry, distribution, western blot, confocal microscopy, antibody

\section{INTRODUCTION}

Cannabinoid receptors and their ligands constitute an endogenous signaling system that is particularly expressed in the CNS (Herkenham et al., 1991; Devane et al., 1992; Stella et al., 1997). This system is activated by exogenous cannabinoids such as $\Delta^{9}$. tetrahydrocannabinol $\left(\Delta^{9}\right.$-THC) and is composed of cannabinoid receptors type $1(\mathrm{CB} 1 \mathrm{R})$ and $2(\mathrm{CB} 2 \mathrm{R})$, the endogenous agonists of these receptors, the endocannabinoids (eCBs) anandamide and 2-arachidonoylglycerol (2-AG), and the enzymes responsible for the biosynthesis and degradation of eCBs (Pertwee et al., 2010). The eCBs are modulators of synaptic transmission throughout the CNS. They act as retrograde inhibitors of neurotransmission and mediate the long-term depression of synaptic responses (Kreitzer and Regehr, 2001; Wilson and Nicoll, 2001; Sjöström et al., 2003). The levels of 2-AG in rodent brains are 800 -fold higher than those of anandamide (Sugiura et al., 1995). Although anandamide binds to CB1R and CB2R with higher affinities than does 2-AG (Mackie et al., 1993), it acts only as a partial agonist, while 2-AG acts as a full agonist (Gonsiorek et al., 2000; Savinainen et al., 2001). On the basis of these differences between 2-AG and anandamide and on recent electrophysiological and anatomical studies, it is currently believed that 2-AG is the most potent natural ligand of cannabinoid receptors and is the key eCB for retrograde signaling in the brain (Sugiura et al., 2006; Katona and Freund, 2008; Tanimura et al., 2010). 2-AG is poorly soluble in the hydrophilic extracellular matrix (Devane et al., 1992; Di Marzo, 2008) and has a brief halflife (Járai et al., 2000). Consequently, its actions are local and dependent on the location of its biosynthesis site and receptors (Di Marzo, 2008). The synthesis of 2-AG is catalyzed primarily by diacylglycerol lipase alpha (DAGL $\alpha$; Gao et al., 2010); $85 \%$ of its degradation is controlled by monoacylglycerol lipase (MAGL), and the enzymes alpha-beta hydrolase domain 6 (ABHD6) and 12 (ABHD12) hydrolyze the remaining 15\% (Blankman et al., 2007).

The eCB system plays an important role in CNS development that includes neuron differentiation (Berghuis et al., 2005), neuronal migration, axon guidance (Argaw et al., 2011; Duff et al., 2013), positioning of cortical interneurons, morphogenesis and the specification and survival of neural progenitors 
(Guzmán et al., 2001; Galve-Roperh et al., 2006; see Harkany et al., 2007 for review). CB1R mRNA expression varies in the forebrain, brainstem and cerebellum during brain development (Berrendero et al., 1998). It has also been demonstrated that 2-AG levels progressively increase in the CNS throughout embryonic development, peak immediately after birth and stabilize during postnatal development (Berrendero et al., 1999; Fride, 2008).

Several constituents of the eCB system are located in the retinas of numerous species from fishes to primates (see Yazulla, 2008 for review). In adult rodents, CB1R, CB2R, DAGL $\alpha$ and MAGL are present in the retina (Hu et al., 2010; Zabouri et al., 2011a; Cécyre et al., 2013). To our knowledge, very few studies have examined the localization and/or effects of eCB biosynthesis and degradative enzymes in the developing retina. The consequences of CB1R modulation in the retinal cells of embryonic and young animals were studied by Lalonde et al. (2006) and Warrier and Wilson (2007). Briefly, these authors reported that CB1R activation modulates GABA release from amacrine cells and inhibits highvoltage-activated calcium channel currents in cultured ganglion cells, thereby affects the excitability of cells. Recently, our research group investigated the spatiotemporal distributions of CB1R and FAAH during postnatal development (Zabouri et al., 2011a,b). Our results demonstrated a differential distribution of CB1R and FAAH during this period. Apart from CB1R and FAAH, the expression and distribution patterns of retinal $\mathrm{eCB}$ system proteins during development remain unknown.

Because DAGL $\alpha$ and MAGL localization dictates 2-AG function, we investigated the spatiotemporal protein expression of DAGL $\alpha$ and MAGL in the rat retina during postnatal development until adulthood. The rodent retina represents a valuable model for the study of development because it includes several cell classes that comprise neuronal and glial cell types and because retinal cells have well-known developmental timelines (Rapaport et al., 2004). The results reported here show that DAGL $\alpha$ is constantly present during postnatal development. However, MAGL protein content is weak until postnatal day (P) 11, after which it increases until the adult age, and its distribution is not uniform throughout the retina. These results are consistent with the hypothesis that the eCB system is involved in the development of the retina during the postnatal period.

\section{MATERIALS AND METHODS ANIMALS}

All procedures were performed in accordance with the guidelines of the Canadian Council on Animal Care and the NIH guidelines for the care and use of laboratory animals, and were approved by the ethics committee on animal research of the Université de Montréal. Gestating adult Long-Evans rats were obtained from Charles River (St-Constant, QC) and maintained on a $12 \mathrm{~h}$ light/dark cycle. At least three pups from three litters were used at each age for the experiments.

\section{TISSUE PREPARATION}

The rats were euthanized at various ages; i.e., P1, 3, 5, 7, 9, 11, $13,15,21,30,45$ and as adults $(\geq \mathrm{P} 60)$. The animals were deeply anesthetized either by hypothermia (pups younger than P5) or with excess of isoflurane inhalation. One eye was immediately removed for western blot analysis. The retina was dissected on ice, promptly frozen and kept at $-80^{\circ} \mathrm{C}$ until further processing. Simultaneously, a transcardiac perfusion was conducted with phosphate-buffered $0.9 \%$ saline (PBS; $0.1 \mathrm{M}, \mathrm{pH} 7.4$ ) followed by phosphate-buffered $2 \%$ formaldehyde. The nasal part of the second eye was marked with a suture and removed. Two small holes were made in the cornea prior to an initial post-fixation in $2 \%$ formaldehyde for $1.5-2 \mathrm{~h}$ depending on the age of the animal (longer times were used for older animals). The cornea and lens were removed, and the eyecups were post-fixed for 10 $30 \mathrm{~min}$ in $2 \%$ formaldehyde. The eyecups were washed in PBS, cryoprotected in 30\% sucrose overnight, embedded in Neg 50 tissue Embedding Media (Fisher Scientific, Ottawa, ON), flashfrozen and kept at $-80^{\circ} \mathrm{C}$. Sections ( $14 \mu \mathrm{m}$ thick) were cut with a cryostat (Leica Microsystems, Concord, ON) and placed on gelatin/chromium coated slides.

\section{WESTERN BLOT}

The retinas were homogenized in RIPA buffer $(150 \mathrm{mM} \mathrm{NaCl}$, 20 mM Tris, $\mathrm{pH}$ 8.0, 1\% NP-40 (USB Corporation, Cleveland, $\mathrm{OH}, \mathrm{USA}), 0.1 \%$ sodium dodecyl sulfate (SDS), $1 \mathrm{mM}$ EDTA), supplemented with a protease inhibitor mixture (aprotinin, leupeptin, pepstatin at $1 \mu \mathrm{g} / \mathrm{ml}$ and phenylmethylsulfonyl fluoride at $0.2 \mathrm{mg} / \mathrm{ml}$; Roche Applied Science, Laval, QC). Thirty micrograms of protein/sample of the homogenate were resolved with 8 or $12 \%$ SDS-polyacrylamide gel electrophoresis (SDSPAGE), transferred onto a nitrocellulose membrane, blocked with $5 \%$ skim milk and incubated overnight with antibodies directed against DAGL $\alpha$, MAGL or $\beta$-actin, the latter served as a loading control. The blots were exposed to the appropriate HRP-coupled secondary antibodies (Jackson Immunoresearch Laboratories, West Grove, PA). Detection was performed using homemade ECL western blotting detection reagent (final concentrations: $2.5 \mathrm{mM}$ luminol, $0.4 \mathrm{mM}$ p-coumaric acid, $0.1 \mathrm{M}$ Tris- $\mathrm{HCl} \mathrm{pH}$ $8.5,0.018 \% \mathrm{H}_{2} \mathrm{O}_{2}$ ). The densitometric analyses were performed using ImageJ software (version 1.47b; Schneider et al., 2012) on scanned films obtained from a series of seven independent blots. Each analysis was performed with retinal samples from distinct experimental groups. The analyses were conducted following the recommendations of a number of reports (Tan and Ng, 2008; Gassmann et al., 2009). Briefly, a standard curve was produced from a serial dilution series to determine the linear dynamic range of detection of each antibody (Suzuki et al., 2011). Several exposure times were tested and only blots exposed below saturation were quantified. The DAGL $\alpha / \beta$-actin and MAGL $/ \beta$-actin ratios were calculated to compensate for the variability in the loading and concentration of the samples.

\section{IMMUNOHISTOCHEMISTRY}

Frozen sections were washed in PBS, post-fixed for $10 \mathrm{~min}$ in cold acetone, washed, and then blocked in 1\% bovine serum albumin (Fisher Scientific, Ottawa, ON), bovine gelatin and $0.5 \%$ Triton X-100 in PBS for $1 \mathrm{~h}$. The sections were incubated overnight in rabbit anti-DAGL $\alpha$ or anti-MAGL solution with an antibody against one of various retinal markers (see Table 1). The sections were subsequently washed in PBS, blocked for 
Table 1 | Antibodies used in this study.

\begin{tabular}{|c|c|c|c|c|}
\hline \multirow{2}{*}{ Antibody } & Immunogen & Provenance & \multirow{2}{*}{$\frac{\text { Dilution* }^{*}}{\mathrm{I}: \text { 1/200W: } 1 / 200}$} & \multirow{2}{*}{$\frac{\text { Host }}{\text { Rabbit }}$} \\
\hline & $\begin{array}{l}\text { C-terminus } 42 \text { amino acids of mouse } \\
\text { DAGL } \alpha \text { (1003-1044 amino acid residues); } \\
\text { affinity purified with antigen polypeptide }\end{array}$ & $\begin{array}{l}\text { DGLa-Rb-Af380, Frontier Institute, } \\
\text { Ishikari, Hokkaido, Japan }\end{array}$ & & \\
\hline MAGL & $\begin{array}{l}\text { N-terminus } 35 \text { amino acids of mouse MAGL } \\
\text { (1-35 amino acid residues); affinity purified } \\
\text { with antigen polypeptide }\end{array}$ & MGL-Rb-Af200, Frontier Institute & I: 1/200W: 1/200 & Rabbit \\
\hline$\beta$-actin & $\begin{array}{l}\text { Modified } \beta \text {-cytoplasmic actin } N \text {-terminal } \\
\text { peptide (DDDIAALVIDNGSGK, conjugated } \\
\text { to } \mathrm{KLH} \text { ) }\end{array}$ & A5316, Sigma-Aldrich, St. Louis, MO & $W: 1 / 2,000$ & Mouse \\
\hline Mouse cone-arrestin (LUMlj) & $\begin{array}{l}\text { C-terminus of the mCAR protein, residues } \\
\text { 369-381; affinity purified with the } \\
\text { immunogen }\end{array}$ & $\begin{array}{l}\text { Dr. Cheryl M. Craft, Mary D. Allen } \\
\text { Laboratory for Vision Research, } \\
\text { Doheny Eye Institute, USC, Los } \\
\text { Angeles, CA }\end{array}$ & I: $1 / 1000$ & Rabbit \\
\hline Recoverin & Full-length recombinant human recoverin & AB5585, Millipore, Billerica, MA & I: $1 / 2,000$ & Rabbit \\
\hline Calbindin & Recombinant rat calbindin D-28k full length & $\begin{array}{l}\text { CB-38a, Swant, Bellinzona, } \\
\text { Switzerland }\end{array}$ & I: 1/1,000 & Rabbit \\
\hline $\mathrm{PKC} \alpha$ & $\begin{array}{l}\text { Synthetic peptide with the sequence } \\
\text { DFEGFSYVNPQFVHPILOSSV from the } \\
\text { human protein }\end{array}$ & $\begin{array}{l}\text { Sc-8393, Santa Cruz Biotechnology, } \\
\text { Santa Cruz, CA }\end{array}$ & I: $1 / 500$ & Mouse \\
\hline Syntaxin & $\begin{array}{l}\text { Synaptosomal plasma fraction of rat hip- } \\
\text { pocampus }\end{array}$ & S0664, Sigma-Aldrich & l: $1 / 500$ & Mouse \\
\hline Brn-3a & $\begin{array}{l}\text { Sequence: GGSAHPHPHMHGLGHLSHPA } \\
\text { AAAAMNMPSGLPHPGLVAA fuzed to the } \\
\text { T7 gene } 10 \text { protein }\end{array}$ & MAB1585, Millipore & I: 1/100 & Mouse \\
\hline Glutamine synthetase (GS) & Full protein purified from sheep brain & MAB302, Millipore & I: $1 / 3,000$ & Mouse \\
\hline CtBP2 & $\begin{array}{l}\text { Amino acids } 431-445 \text { of rat CtBP2 coupled } \\
\text { to keyhole limpet hemocyanin via added } \\
\text { N-terminal Cys-residue; affinity purified with } \\
\text { the immunogen }\end{array}$ & $\begin{array}{l}\text { 193003, Synaptic Systems, } \\
\text { Göttingen, Germany }\end{array}$ & I: $1 / 10,000$ & Rabbit \\
\hline PSD95 & Recombinant rat PSD-95 & MAB1596, Millipore & l: $1 / 200$ & Mouse \\
\hline VGlut1 & $\begin{array}{l}\text { Synthetic peptide representing amino acids } \\
456-560 \text { of rat vesicular glutamate trans- } \\
\text { porters (VGlut1); affinity purified with the } \\
\text { immunogen }\end{array}$ & 135303, Synaptic Systems & l: $1 / 10,000$ & Rabbit \\
\hline MAP2 & Bovine microtubule-associated protein 2 & M1406, Sigma-Aldrich & l: $1 / 500$ & Mouse \\
\hline PCNA & $\begin{array}{l}\text { Synthetic peptide with the sequence } \\
\text { LVFEAPNOEK }\end{array}$ & $\begin{array}{l}\text { M0879, Dako, Burlington, ON, } \\
\text { Canada }\end{array}$ & l: $1 / 500$ & Mouse \\
\hline Alexa Fluor 488 donkey anti-mouse & $\begin{array}{l}\text { Mouse (used against PKC } \alpha \text {, syntaxin, Brn- } \\
\text { 3a, GS, PSD95, MAP2 and PCNA) }\end{array}$ & $\begin{array}{l}\text { A-21202, Molecular Probes, } \\
\text { Eugene, OR }\end{array}$ & I: $1 / 500$ & Donkey \\
\hline Alexa Fluor 488 donkey anti-rabbit & $\begin{array}{l}\text { Rabbit (used against mouse cone-arrestin, } \\
\text { recoverin, calbindin, CtBP2 and VGlut1) }\end{array}$ & A-21206, Molecular Probes & l: $1 / 500$ & Donkey \\
\hline Alexa Fluor 647 donkey anti-rabbit & Rabbit (used against DAGL $\alpha$ and MAGL) & A-31573, Molecular Probes & I: $1 / 500$ & Donkey \\
\hline Alexa Fluor 647 donkey anti-goat & $\begin{array}{l}\text { Goat (used against DAGL } \alpha \text { and MAGL, for } \\
\text { same hosts labeling) }\end{array}$ & A-21447, Molecular Probes & l: $1 / 500$ & Donkey \\
\hline Peanut agglutinin (PNA) & $\begin{array}{l}\text { No immunogen; binds to galactosyl }(b-1,3) \\
\text { N-acetylgalactosamine, rhodamine labeled }\end{array}$ & $\begin{array}{l}\text { RL-1072, Vector Laboratories, } \\
\text { Burlingame, CA }\end{array}$ & I: $1 / 5,000$ & - \\
\hline
\end{tabular}

*I, immunohistochemistry; W, Western blot.

$30 \mathrm{~min}$, and incubated for $1 \mathrm{~h}$ with the appropriate secondary antibodies, washed and mounted with PVA-Dabco mounting medium. Because antibodies to several retinal cell markers were raised in the same host as those for DAGL $\alpha$ and MAGL (recoverin, mouse cone-arrestin, calbindin, CtBP2 and VGlut1), these combinations required sequential incubations as previously described 
by our research group (Zabouri et al., 2011a,b) and others (Sherry et al., 2003). Briefly, the sections were labeled in a serial manner: the exposure to the first primary antibody was conducted as described above, followed by incubation in a goat anti-Fab fragment solution (Jackson Immunoresearch Laboratories). This allowed us to tag the first primary antibody as a goat rather than a rabbit. The sections were revealed with a secondary Alexa donkey anti-goat 633. The sections were then exposed to a second primary antibody overnight, and the latter was revealed with an Alexa donkey anti-rabbit 488 the following day. The dilution factors, immunogens, and provenance of the antibodies are provided in Table 1.

\section{VALIDITY OF THE SEQUENTIAL LABELING}

The validity of the sequential labeling was verified for the rabbitrabbit co-labeling with two controls. Briefly: (1) the second primary antibody was omitted, which yielded strong labeling with the goat secondary 633 and no labeling with the rabbit secondary 488; and (2) the first secondary and second primary antibodies were omitted, which yielded no signal for the goat secondary 633 and a low residual signal for the rabbit secondary 488. These control experiments demonstrated the specificity of the sequential Fab fragment protocol and were conducted systematically (data not show). Identical results have been presented in recent reports from our research group (Zabouri et al., 2011a,b).

\section{ANTIBODY CHARACTERIZATION}

The DAGL $\alpha$ and MAGL antibodies have been fully characterized in the hippocampi of DAGL $\alpha$ and MAGL knockout mice (Yoshida et al., 2006; Uchigashima et al., 2011). Although DAGL $\alpha$ and MAGL share $100 \%$ homology in their protein sequence between rats and mice, we tested their specificities in the rat retina using western blotting. The anti-DAGL $\alpha$ and the anti-MAGL reacted with bands at approximately 120 and $33-\mathrm{kDa}$, respectively (Figure 1A), as described by other authors (Dinh et al., 2002; Yoshida et al., 2006; Suárez et al., 2008; Gao et al., 2010; Rivera et al., 2014). When the antibodies were pre-adsorbed with their respective blocking peptide, no immunoreactivity was detected in the adult rat retina (Figure 1B).

The mouse monoclonal antibody against beta-actin ( $\beta$-actin) was raised against a slightly modified $\beta$-cytoplasmic actin $\mathrm{N}$ terminal peptide (DDDIAAVIANGSGL). During western blotting, the $\beta$-actin antibody detects a single band at the expected molecular weight of $42 \mathrm{kDa}$ (Gribaudo et al., 2009; Arellano et al., 2012).

The rabbit polyclonal antibody against mouse cone-arrestin was directed against the C-terminus epitope of the mCAR protein and detects a single band at $44 \mathrm{kDa}$ in the mouse retina (Zhu et al., 2002, 2003; Nikonov et al., 2008). This antibody labels cone photoreceptors in the rat retina (Bobu et al., 2008; Bobu and Hicks, 2009).

The rabbit polyclonal antibody against recoverin was raised against recombinant human protein and recognizes a $25-\mathrm{kDa}$ protein in the mouse retina. This calcium-binding protein has been detected in photoreceptors and cone bipolar cells of the retina, including the retinas of primates (Haverkamp and Wässle,
2000; Hendrickson et al., 2009) and rats (Milam et al., 1993; Chun et al., 1999; Günhan et al., 2003).

The rabbit polyclonal antibody against calbindin was directed against recombinant rat calbindin $\mathrm{D}-28 \mathrm{~K}$ protein. This antibody detects a $28-\mathrm{kDa}$ band on immunoblots and labels horizontal, ON cone bipolar cells and amacrine cell processes (Mitchell et al., 1995; Massey and Mills, 1996; Morgan et al., 2006; Hirano et al., 2011; Matsuoka et al., 2011). It labels horizontal cells (Pasteels et al., 1990; Peichl and González-Soriano, 1994) and amacrine cell processes in the rat retina (Mojumder et al., 2008).

The mouse monoclonal antibody against PKC $\alpha$ is specifically expressed in rod bipolar cells and dopaminergic amacrine cells (Negishi et al., 1988). Mouse anti-PKC $\alpha$ has been shown to exclusively recognize rod bipolar cells in the rat retina (Euler and Wässle, 1995; Johansson et al., 2000; Zabouri et al., 2011a). This antibody recognizes $\mathrm{PKC} \alpha$ at approximately $80-\mathrm{kDa}$ (Nagar et al., 2009). The immunoreactive pattern that we observed was similar to that reported in previous studies (Negishi et al., 1988; Gaillard et al., 2008).

The mouse monoclonal antibody against syntaxin-1 has been recognized as a specific marker of retinal amacrine cells by several research teams (Hirano et al., 2005; Li et al., 2010). Mouse antisyntaxin recognizes syntaxin-1, which is a $35-\mathrm{kDa}$ protein, in hippocampal, retinal and cortical neurons (Inoue et al., 1992). This antibody labels amacrine cells in the rat retina (Zabouri et al., 2011a; Kunzevitzky et al., 2013). The immunoreactive pattern observed in the present study was similar to that which has previously been reported (Li et al., 2004).

The mouse monoclonal antibody against Brn-3a labels only retinal ganglion cells in the retinas of several species (Gerrero et al., 1993; Xiang et al., 1995; Voinescu et al., 2009). According to the manufacturer, this antibody detects a $46-\mathrm{kDa}$ band, does not recognize Brn-3b or Brn-3c, and does not label tissue from Brn-3a knockout mice. Brn-3a expression has been shown in the rat retina (Nadal-Nicolás et al., 2009; Zabouri et al., 2011a). Brn-3a labels the vast majority of ganglion cells but does not label intrinsically photosensitive retinal ganglion cells (ipRGCs; Jain et al., 2012).

The expression of glutamine synthetase (GS) in Müller cells has been demonstrated, and it has been established that the mouse monoclonal anti-GS labels a single $45-\mathrm{kDa}$ band in adult rat retinal tissue (Chang et al., 2007). The labeling obtained with this antibody was comparable to that published elsewhere (Gargini et al., 2007; Kim et al., 2008).

The rabbit polyclonal antibody against the C-terminal binding protein 2 ( $\mathrm{CtBP} 2)$ recognizes ribbons in mammalian retina and produces a distinctive immunoreactivity pattern of horseshoeshaped synaptic ribbons in the outer nuclear layer (ONL) and dense punctae in the inner plexiform layer (IPL). The antiserum recognizes a $110-120-\mathrm{kDa}$ protein band and a $50-\mathrm{kDa}$ protein band (tom Dieck et al., 2005), and has been tested in the rat retina (Østergaard et al., 2007).

The mouse monoclonal antibody to postsynaptic density protein 95 (PSD-95) detects a single band at approximately $100 \mathrm{kDa}$, which corresponds to the apparent molecular weight of PSD-95 on SDS-PAGE immunoblots from rat, mouse and bovine brains (manufacturer's data sheet). The antibody also detects a minor 
A

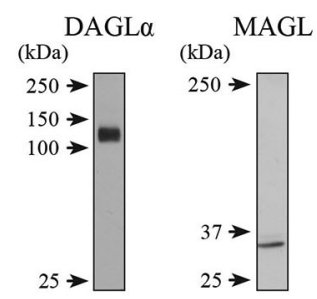

B

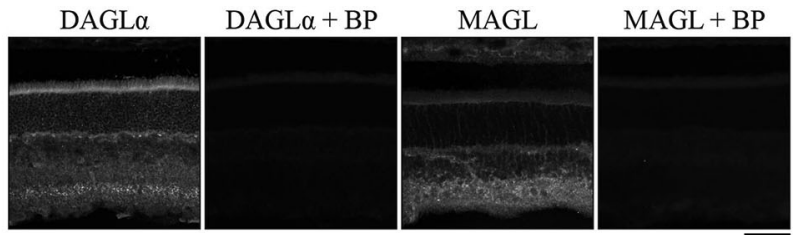

C

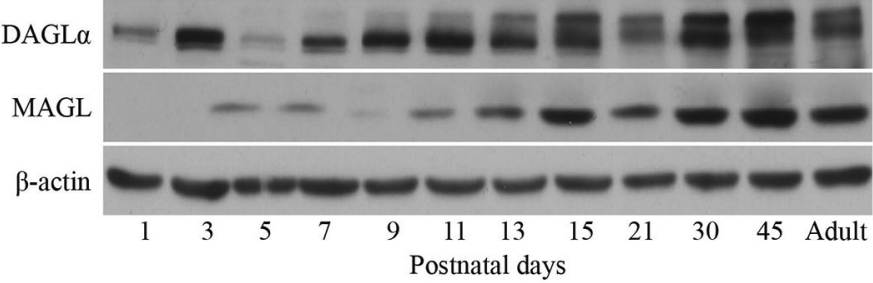

D

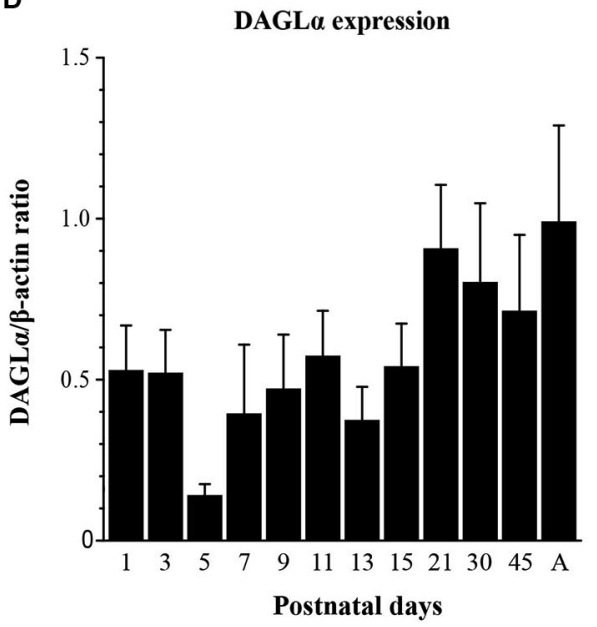

FIGURE 1 | Temporal patterns of protein contents of DAGL $\alpha$ and MAGL during retinal development. (A) Characterization of the antibodies used against DAGL $\alpha$ and MAGL in the adult rat retina. Specific bands were seen at approximately 120 and 33-kDa for DAGL $\alpha$ and MAGL respectively. (B) DAGL $\alpha$ and MAGL expression in the adult rat retina in the presence or not of their respective blocking peptide (BP). Scale bar $=50 \mu \mathrm{m}$. (C) Representative examples of DAGL $\alpha$ and MAGL protein content during retinal development.
E

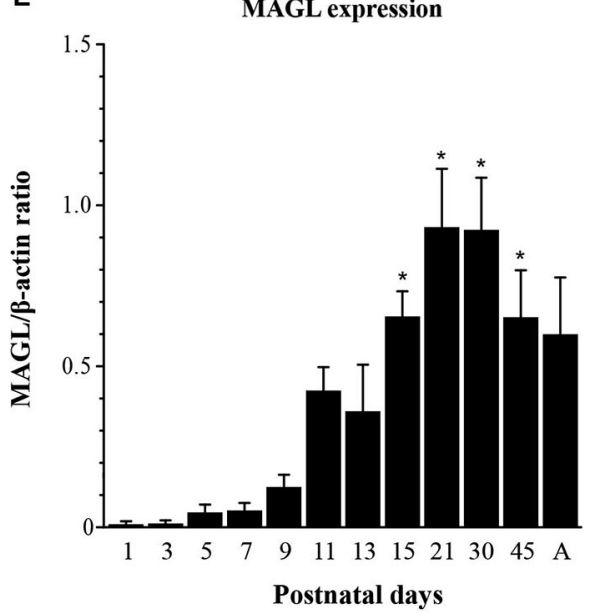

(D,E) Average variations of DAGL $\alpha$ and MAGL during retinal postnatal development and maturation as measured by western blot analysis. Retinas were collected from rats between $\mathrm{P} 1$ and adulthood. The quantifications were performed on seven different sets of samples and mean optical density ratios \pm SEM are presented for each age group. The statistical differences were assessed using a one-way ANOVA, Bonferroni post hoc-test. * Significant change compared to P1 $(P<0.05)$. band at approximately $75 \mathrm{kDa}$ on western blots of mouse and rat brain extracts (manufacturer's data sheet). In the rat retina, PSD-95 immunoreactivity is localized to photoreceptor terminals (Koulen et al., 1998; Li et al., 2012).

The rabbit polyclonal antibody against vesicular glutamate transporter 1 (VGlut1) was raised against a fusion protein containing amino acid residues $456-560$ of rat VGlut1. This antibody recognizes a single $60-\mathrm{kDa}$ band on western blots from the synaptic vesicle fraction of rat brains (Takamori et al., 2000). VGlut1 immunoreactivity is visible in photoreceptor and bipolar cell terminals of the rat retina (Johnson et al., 2007; Stella et al., 2008).

The mouse monoclonal antibody against microtubuleassociated protein 2 (MAP2) recognizes a single 220-kDa band of rat brain (manufacturer's data sheet) and specifically labels cell bodies and processes of ganglion cells in the rat retina (Okabe et al., 1989; Seki et al., 2003).
The mouse monoclonal antibody against proliferating cell nuclear antigen (PCNA) was chosen as a progenitor cell marker because it provides the least false positive and negative immunolabeling of progenitor cells in the retina (Barton and Levine, 2008). This antibody has been shown to label progenitor cell in the rat retina (Nakajima et al., 2001; Zabouri et al., 2011a). The specificity of this antibody has been fully characterized, and it recognizes a single band at $36 \mathrm{kDa}$ (Waseem and Lane, 1990; Ino and Chiba, 2000; Pellegrini et al., 2007).

\section{CONFOCAL MICROSCOPY}

Images of the central retina (within $200 \mu \mathrm{m}$ of the optic nerve head) were taken using a laser scanning confocal microscope (TCS SP2, Leica Microsystems) with 40X (NA: 1.25) or 100X (NA: 1.40) oil immersion objectives and 488 and $633 \mathrm{~nm}$ lasers. Image stacks $(1,024 \times 1,024$ pixels $\times 0.5 \mu \mathrm{m}$ per stack $)$ were captured with a frame average of 3 using the LCS software (version 
2.6.1; Leica Microsystems). Offline processing was performed with the Fiji software (version 1.47g; Schindelin et al., 2012). The stack images were taken sequentially and in distant wavelengths to ensure no "bleed-through" between channels. All images in which labeling intensities were compared were obtained under identical conditions of gain intensity. The Gaussian noise from the images was partially removed using the PureDenoise plugin for Fiji (Luisier and Blu, 2008), and the stacks were collapsed into projection images. Because gray scale photographs provide better contrast and more detail, individual channels are presented in gray scale, and the merged images are presented in color.

\section{RESULTS}

\section{WESTERN BLOT ANALYSIS}

The temporal patterns of expression of two elements of the eCB system in the retina were investigated by evaluating the total amounts of DAGL $\alpha$ and MAGL at various postnatal time points from P1 to adulthood. Representative examples of each enzyme are presented in Figure 1C. The lower blot displays the protein content of $\beta$-actin and demonstrates equal loading in all lanes. The averaged ratios of the optical densities are presented in Figures 1D,E, respectively. These proteins varied across development and exhibited different patterns. The DAGL $\alpha$ protein content was fairly stable from P1 to adulthood (no significant differences compared to P1, one-way ANOVA, Bonferroni post hoctest, $p<0.05)$. In contrast, the amounts of MAGL protein were very low from P1 to P13, and then increased from P15 until P45 $(\mathrm{P} 15,21,30$ and 45 were all significantly different from P1 to P7, one-way ANOVA, Bonferroni post hoc-test, $p<0.05)$.

\section{IMMUNOHISTOCHEMISTRY}

DAGL $\alpha$ was present in the neuroblast, inner plexiform and ganglion cell layers (NBL, IPL and GCL, respectively; Figure 2A) at P1. By P5, DAGL $\alpha$ immunoreactivity was largely upregulated, as indicated by the increased fluorescence exhibited by immunopositive cells compared to P1 (Figure 2B), which was present primarily in the GCL and in the inner nuclear layer (INL). At P11, DAGL $\alpha$ immunoreactivity was visible in the ONL, the outer plexiform layer (OPL), INL, IPL and GCL (Figure 2C). At P21, DAGL $\alpha$ localization remained similar (Figure 2D). This spatial profile was maintained over the following weeks (Figure 2E) until adulthood (Figure 2F) with increased fluorescence in the IPL. MAGL was not detectable in any neural layers of the retina at P1, but was weakly expressed exclusively in the retinal pigment epithelium (RPE; Figure 2G). At P5, MAGL immunoreactivity was barely visible in the RPE, the IPL and the GCL (Figure $2 \mathbf{H}$ ). At P11, MAGL was present in the RPE, OPL, INL, IPL and GCL (Figure 2I). This expression pattern remained unchanged at P21, with the exception that MAGL was no longer present in the RPE (Figure 2J) over the following weeks (Figure 2K) until adulthood (Figure 2L).

\section{CELLULAR DISTRIBUTION OF DAGL $\alpha$ AND MAGL Cone photoreceptors}

$D A G L \alpha$. Cones constitute the last class of early-born neurons to be generated (Rapaport et al., 2004). From P1 until P7, DAGL $\alpha$ was present in the outer segments but not in the pedicles of the cones (Figures 3A-C). By P21, the majority of cones reach their final position in the ONL, and they intensely expressed DAGL $\alpha$ in all of their cellular compartments except the cone pedicles (Figures 3D-F). Over the following weeks, DAGL $\alpha$ expression remained elevated in the outer and inner segments until the animal reached adulthood (Figures 3G-I). However, DAGL $\alpha$ was not expressed in the pedicles of the cones, but did seem to be present postsynaptically to these pedicles (Figures 3J-L).

MAGL. MAGL was not detectable in cone photoreceptors during retinal development in any of the cone cellular compartments (Figures 3M-U). MAGL expression in the ONL was exclusively localized to Müller cells (a detailed localization is presented in Figure 10).

\section{Rod photoreceptors}

$D A G L \alpha$. Rods compose the vast majority of photoreceptors in the rat retina. In this study, the rods were discriminated from cones on the basis of their morphology. Starting from $\mathrm{P} 1, \mathrm{DAGL} \alpha$ was expressed in somas of rods and in their inner and outer segments (Figures $4 \mathrm{~A}-\mathrm{C}$ ). This expression remained constant through the second to the end of the third week of life (Figures 4D-F) and into adulthood (Figures 4G-I).

MAGL. MAGL was not detectable in any of the rod cellular compartments (Figures 4J-R). The immunoreactivity visible in the ONL was localized to Müller cells (Figure 10).

\section{Horizontal cells}

$D A G L \alpha$. Starting from P1 and until P7, DAGL $\alpha$ expression was observed in the dendritic terminals of the horizontal cells (Figures 5A-C). This expression remained constant during the second and third weeks of life (Figures 5D-F), and until adulthood (Figures 5G-L).

MAGL. MAGL was not detectable in the OPL from P1 to P7 (Figures 5M-O). Starting from P11 and through to P45, light expression of MAGL was visible in the OPL but not in the horizontal cells (Figures 5P-R). This expression pattern was conserved in adulthood (Figures $5 \mathbf{S}-\mathbf{U}$ ).

\section{Cone bipolar cells}

$D A G L \alpha$. Recoverin was also used as a marker to investigate DAGL $\alpha$ and MAGL expression in type 2 and 8 cone bipolar cells. This marker is present in type 2 OFF and type $8 \mathrm{ON}$ cone bipolar cells. At P7, no recoverin-positive neurons expressed DAGL $\alpha$ (Figures 6A-C). The labeling of the somas remained the same from P15 (Figures 6D-F) to adulthood (Figures 6G-I), and neither type 2 nor 8 cone bipolar cells expressed DAGL $\alpha$.

MAGL. MAGL was not detectable in recoverin neurons at P7 (Figures 6J-L). By P15, MAGL was still absent from cone bipolar cells (Figures 6M-O). MAGL remained undetectable in recoverin neurons by adulthood (Figures 6P-R). 


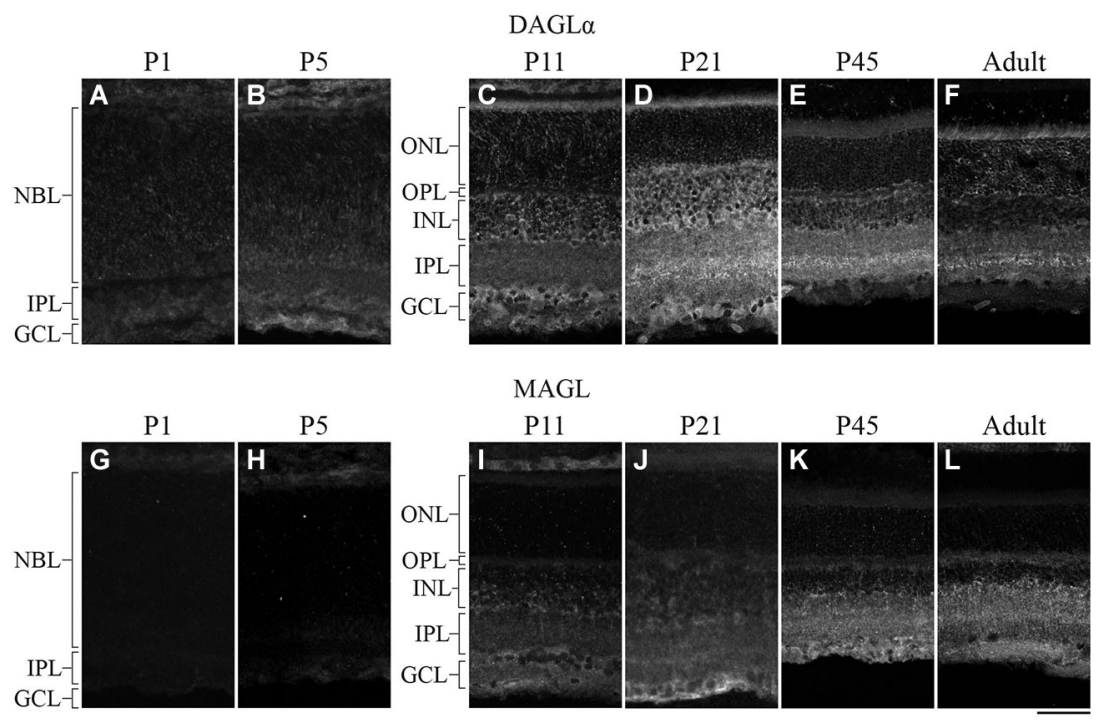

FIGURE 2 | DAGL $\alpha$ and MAGL immunoreactivity in the developing rat retina. (A-L) DAGL $\alpha(\mathbf{A}-\mathbf{F})$ and MAGL $(\mathbf{G}-\mathbf{L})$ protein expressions were obtained with vertical sections from P1, P5, P11, P21, P45 and adult retinas.
GCL, ganglion cell layer; INL, inner nuclear layer; IPL, inner plexiform layer; $\mathrm{NBL}$, neuroblast layer; ONL, outer nuclear layer; OPL, outer plexiform layer. Scale bar $=50 \mu \mathrm{m}$.

\section{Rod bipolar cells}

$D A G L \alpha$. Before P7, the majority of PKC-positive cells were either rod bipolar cells or amacrine cells. These cells could not be differentiated because most rod bipolar cells have not yet reached their final location at this stage. At P7, when the differentiation of the cells became clearer, DAGL $\alpha$ was absent from the somas of the rod bipolar cells (Figures 7A-C). The DAGL $\alpha$ signal remained similar at P15 (Figures 7D-F) and through adulthood (Figures 7G-I). Moreover, DAGL $\alpha$ was not expressed in the dendritic connections of rod bipolar cells.

MAGL. MAGL was not detectable in PKC neurons at P7 (Figures 7J-L). By P15, MAGL was still absent from rod bipolar cells (Figures $7 \mathbf{M}-\mathbf{O}$ ). This protein expression pattern continued into adulthood (Figures 7P-R).

\section{Amacrine cells}

$D A G L \alpha$. DAGL $\alpha$ was expressed in amacrine cells during the first week of life (Figures 8A-C). All amacrine cells expressed DAGL $\alpha$ at P21 (Figures 8D-F) and through adulthood (Figures 8G-I).

MAGL. MAGL was not detectable in amacrine cells at P7 (Figures 8J-L), but an upregulation occurred from P11 (data not shown) and was also present at P21 (Figures $8 \mathbf{M}-\mathbf{O}$ ). MAGL was still expressed in amacrine cells in the adult animals (Figures 8P-R).

\section{Ganglion cells}

$D A G L \alpha$. The spatial organization of DAGL $\alpha$ localization in ganglion cells did not vary with time. Examples of this expression are shown in Figures 9A-I. As expected, a decrease in the number of ganglion cells with age was observed. Moreover, GCL cells other than RGCs were also immunopositive; these cells might have been displaced amacrine cells or ipRGCs.

MAGL. At around P7, there was light expression of MAGL in the GCL but not in the ganglion cells (Figures 9J-L). From P21 to adulthood, the MAGL immunoreactivity intensity was elevated in the GCL but remained unobservable in the ganglion cells (Figures 9M-R).

\section{Müller cells}

$D A G L \alpha$. Müller cells are generated late in development and begin to express GS at around P5. However, they are not clearly distinguishable until P11 and did not express DAGL $\alpha$ in their cell bodies or processes (Figures 10A-C). DAGL $\alpha$ was still undetectable in Müller cells from P21 (Figures 10D-F) to adulthood (Figures 10G-I).

MAGL. MAGL was expressed in the processes but not in the cell bodies of the Müller cells at P11 (Figures 10J-L). From P21, MAGL was present in the outer processes of Müller cells but remained absent from their cell bodies (Figures 10M-R). In adulthood, MAGL was expressed in the outer and inner processes of Müller cells but not in their cell bodies (Figures 10S-AA).

\section{Outer plexiform layer}

$D A G L \alpha$. In the previous paragraphs, DAGL $\alpha$ was shown to be located in the OPL, specifically in the dendritic terminals of the horizontal cells (Figures 5A-L) and not in the pedicles of the cones (Figures 3J-L) or the dendritic connections of the rod bipolar cells (Figures 7G-I). We carefully examined whether this OPL labeling was exclusive to the horizontal cells. From P7 to adulthood, DAGL $\alpha$ was also expressed in the cytoplasm of the photoreceptor terminals (Figures 11A-F). 


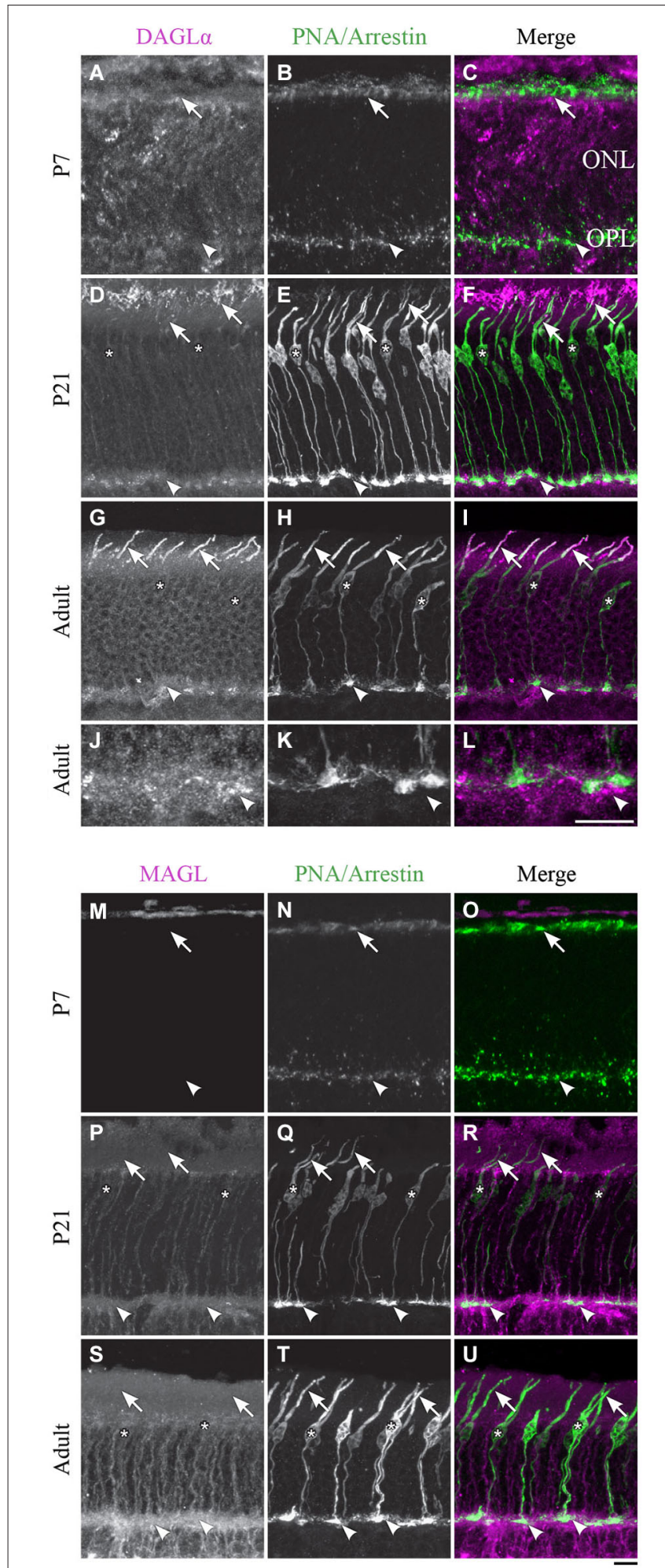

FIGURE 3 | DAGL $\alpha$ and MAGL immunoreactivity in cone photoreceptors. (A-U) confocal micrographs of P7, P21 and adult rat retinas co-labeled for DAGL $\alpha(\mathbf{A}-\mathbf{L})$ or MAGL $(\mathbf{M}-\mathbf{U})$ and the cell-type specific marker for cone photoreceptors, PNA (for P7) or cone-arrestin (for P21 and adult). Each protein is presented alone in gray scale: DAGL $\alpha$ or

(Continued)

\section{FIGURE 3 | Continued}

MAGL in the first column and PNA/cone-arrestin in the second; then the two are presented merged in the third column (DAGL $\alpha$ or MAGL in magenta and PNA/cone-arrestin in green). DAGL $\alpha$ is localized in the outer (arrows) and inner segments of cones, as well as the cell body (stars) but not the synaptic pedicle (arrowheads). MAGL is not detectable in any part of the cone photoreceptors. ONL, outer nuclear layer; OPL, outer plexiform layer. Scale bar $=10 \mu \mathrm{m}$

\section{Inner plexiform layer}

$D A G L \alpha$. During development, strong DAGL $\alpha$ labeling was visible in the IPL. The antibody VGlut1 revealed the presence of DAGL $\alpha$ in the axon terminals of the bipolar cells (Figures 11G-I). Using the antibody recoverin, we determined that DAGL $\alpha$ was not expressed in the axon terminals of the type 2 or 8 cone bipolar cells (Figures 11J-L). The antibody PKC $\alpha$ revealed that DAGL $\alpha$ was not present in the axon terminals of the rod bipolar cells (Figures $11 \mathrm{M}-\mathrm{O}$ ). Finally, the antibodies calbindin and MAP2 confirmed that DAGL $\alpha$ was absent from the dendrites of the amacrine (Figures 11P-R) and ganglion cells (Figures 11S-U), respectively.

MAGL. From P21 to adulthood, a MAGL labeling was visible in the IPL. The antibody CtBP2 revealed the presence of MAGL in the axon terminals of bipolar cells (Figures 12A-C). We then determined that MAGL appeared to be present in the axon terminals of the type 2 OFF but not in the type 8 ON cone bipolar cells (Figures 12D-F). The antibody PKC $\alpha$ revealed that MAGL was not present in the axon terminals of the rod bipolar cells (Figures 12G-I). Finally, the antibodies calbindin and MAP2 confirmed that MAGL was not expressed in the dendrites of the amacrine (Figures 12J-L) or ganglion cells (Figures 12M-O).

\section{Progenitor cells}

$D A G L \alpha$. At P1, the progenitor cells were DAGL $\alpha$-positive (Figures 13A-C), and the same pattern of expression was visible at P5 (Figures 13D-F) and P7 (Figures 13G-I).

MAGL. MAGL was not detectable in the progenitor cells at P1 (Figures 13J-L), and this pattern remained unchanged at P5 and P7 (Figures 13M-R).

\section{Comparison of the temporal and spatial profiles of DAGL $\alpha$ and MAGL protein localization}

The timelines of DAGL $\alpha$ and MAGL localization in all of the retinal cells studied are shown in Figure 14A. These timelines were constructed based on detailed analyses of the expressions of both proteins in each cell type. From this figure, it can be seen that, during the first week of life, DAGL $\alpha$ was highly expressed in every cell type, while MAGL was not present in any of these cells. From P11, the two proteins were only co-expressed in amacrine cells. MAGL was present in the Müller cells from P11, while DAGL $\alpha$ was never expressed in these cells. In the adult retina, DAGL $\alpha$ and MAGL were only co-expressed in the amacrine cells. Hypothetical mechanism of 2-AG action on the retinal synapses of adult animals is presented in Figure 14B. 


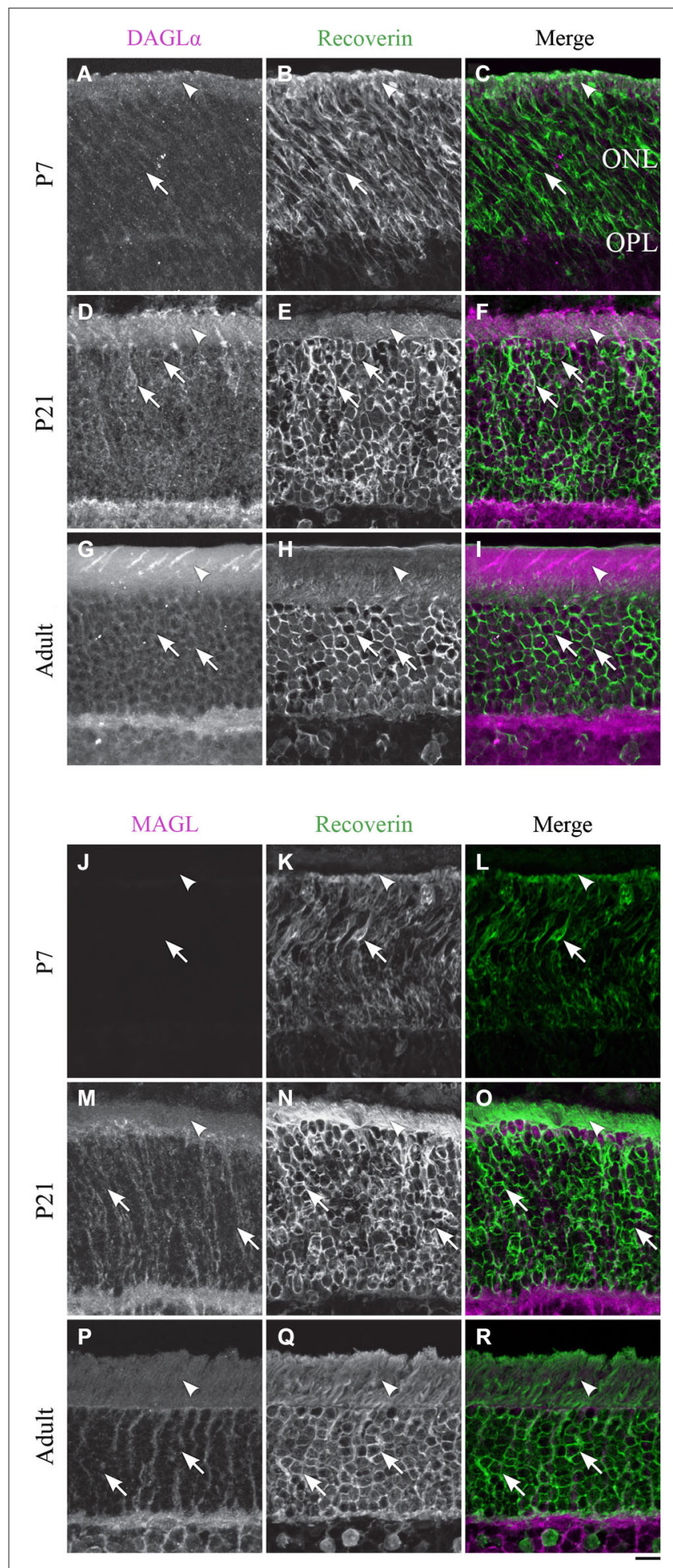

FIGURE 4 | DAGL $\alpha$ and MAGL immunoreactivity in rod photoreceptors. (A-R) confocal micrographs of P7, P21 and adult rat retinas

co-immunolabeled for DAGL $\alpha(\mathbf{A}-\mathbf{I})$ or MAGL (J-R) and the cell-type marker for photoreceptors, recoverin. DAGL $\alpha$ is localized in the outer (arrowheads) and inner segments of the rods (arrows). MAGL is not detectable in any part of the rod photoreceptors. ONL, outer nuclear layer; OPL, outer plexiform layer. Scale bar $=10 \mu \mathrm{m}$.

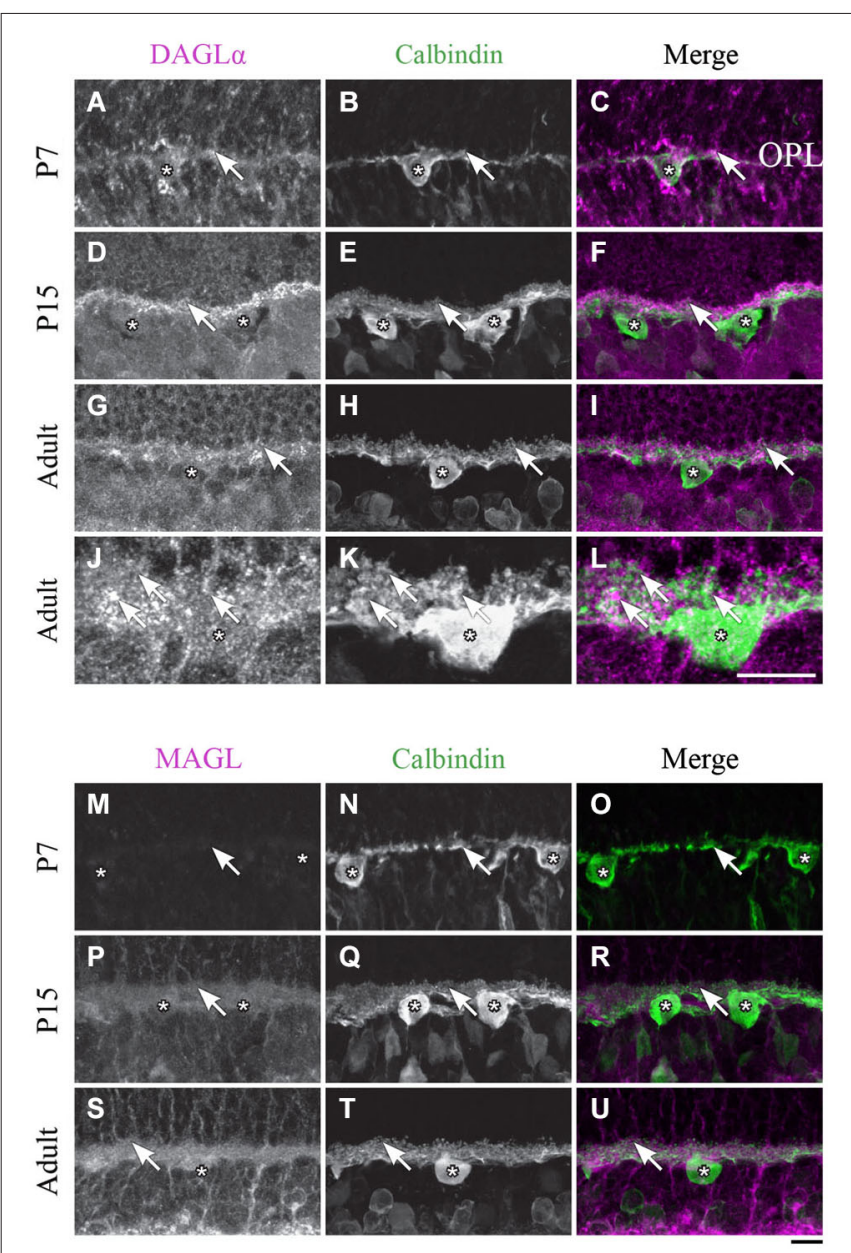

FIGURE 5 | DAGL $\alpha$ and MAGL immunoreactivity in horizontal cells (A-U) confocal micrographs of P7, P15 and adult rat retinas co-immunolabeled for DAGL $\alpha(\mathbf{A}-\mathbf{L})$ or MAGL (M-U) and the cell-type specific marker for horizontal cells, calbindin. DAGL $\alpha$ is present in the dendritic terminals (arrows) but not in the cell bodies of the horizontal cells (stars). MAGL is not detectable in any part of the horizontal cells. OPL, outer plexiform layer. Scale bar $=10 \mu \mathrm{m}$

\section{DISCUSSION}

This study is the first to investigate the protein localization of DAGL $\alpha$ and MAGL, which are two key enzymes of the eCB system, during the postnatal development of the retina. Using immunohistological labeling and immunoblots, we showed that the protein content of DAGL $\alpha$ remains constant after birth, while that of MAGL varies during postnatal development and the maturation of the rat retina. Our data provide evidence of the early and widespread presence of DAGL $\alpha$.

\section{TEMPORAL EXPRESSION OF DAGL $\alpha$ AND MAGL}

We observed that the amount of DAGL $\alpha$ protein was constant during retinal development. These results are in agreement with previous reports that have suggested that DAGL $\alpha$ protein levels remain stable during brain development (for review, see AnaviGoffer and Mulder, 2009). Conversely, the MAGL protein content 


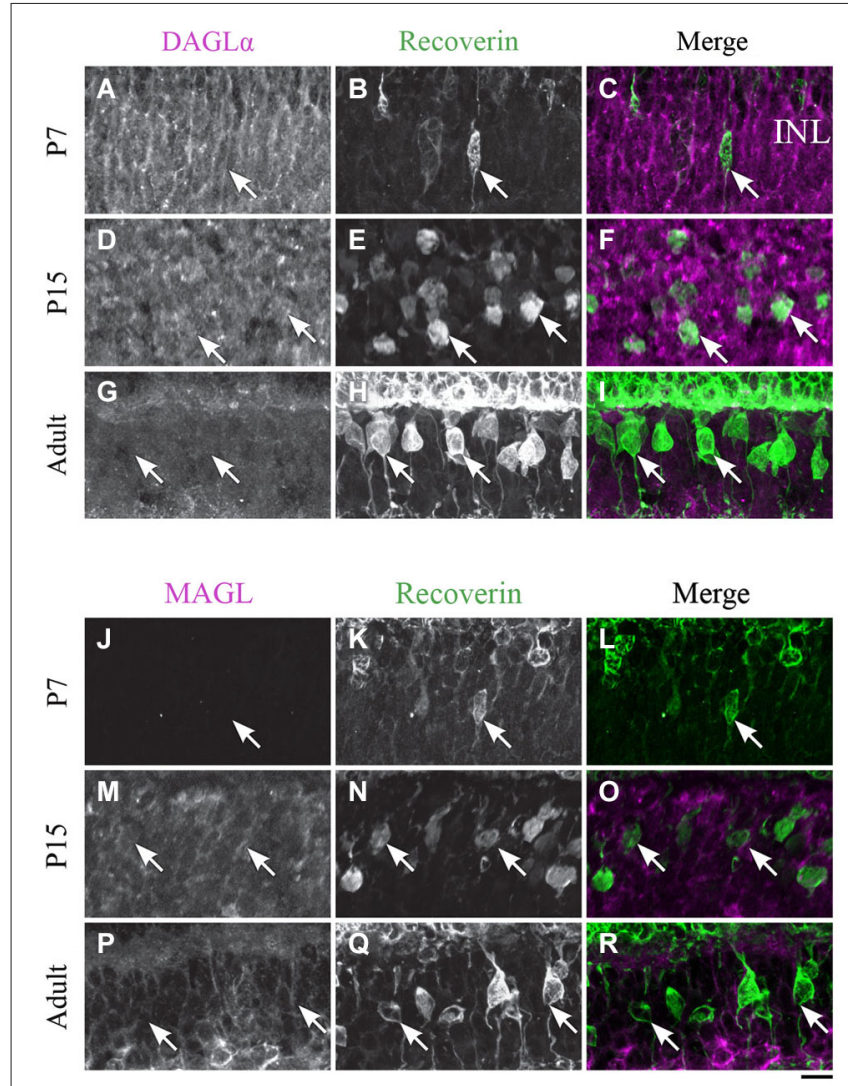

FIGURE 6 | DAGL $\alpha$ and MAGL immunoreactivity in type 2 and 8 cone bipolar cells. (A-R) confocal micrographs of P7, P15 and adult rat retinas co-immunolabeled for DAGL $\alpha(\mathbf{A}-\mathbf{I})$ or MAGL (J-R) and the cell-type marker for type 2 and 8 cone bipolar cells, recoverin. DAGL $\alpha$ is not expressed in the cell bodies (arrows) of type 2 or 8 cone bipolar cells. MAGL is not detectable in type 2 or 8 cone bipolar cells. INL, inner nuclear layer. Scale bar $=10 \mu \mathrm{m}$.

was low from P1 to P13 and subsequently gradually increased from P15 to P45. Based on these results, we hypothesize that 2-AG levels are elevated from birth to $\mathrm{P} 13$ and are then regularized from P15 to adulthood. Hence, these results are in accordance with those of previous reports that have shown rapid increases in 2-AG levels immediately after the birth that are followed by stabilization during postnatal development (Berrendero et al., 1999; Fride, 2008).

\section{CELLULAR LOCALIZATION OF DAGL $\alpha$ AND MAGL Cellular localization of DAGL $\alpha$}

DAGL $\alpha$ was present in the majority of early-born neurons as early as P1. This finding is in accordance with previous reports that have shown that DAGL $\alpha$ is expressed in the rostral migratory stream of young mice (Oudin et al., 2011). Hence, in the adult, we showed that DAGL $\alpha$ was present in cone and rod photoreceptors, horizontal cell processes, some cone bipolar cell axon terminals, amacrine cells, and ganglion cells. This expression pattern contrasts with that previously described for the mouse retina (Hu et al., 2010) in which DAGL $\alpha$ is present in postsynaptic terminals of type 1 OFF

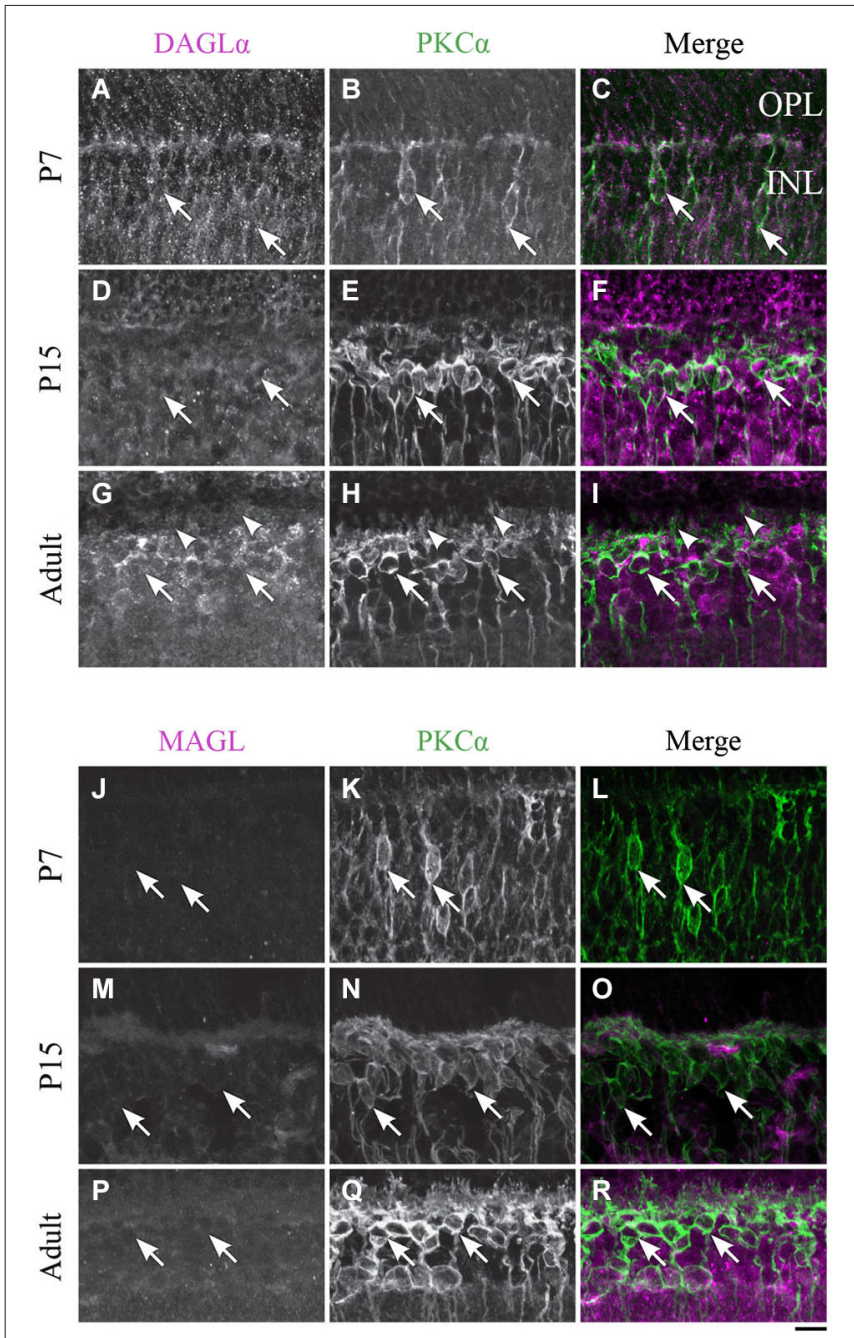

FIGURE 7 | DAGL $\alpha$ and MAGL immunoreactivity in rod bipolar cells. (A-R) confocal micrographs of P7, P15 and adult rat retinas co-immunolabeled for DAGL $\alpha(\mathbf{A}-\mathbf{I})$ or MAGL (J-R) and the cell-type specific marker for the rod bipolar cells, PKC $\alpha$. DAGL $\alpha$ and MAGL are not detectable in the cell bodies (arrows) or dendritic connections of the rod bipolar cells. $\mathrm{OPL}$, outer plexiform layer; INL, inner nuclear layer. Scale bar $=10 \mu \mathrm{m}$.

cone bipolar cells and is widely and diffusely distributed in the IPL. However, these findings are not in complete opposition with ours because we noted strong labeling in the OPL, which might correspond to the dendritic connections of cone bipolar cells, and in the IPL. This difference might be attributable to species differences in DAGL $\alpha$ expression between rats and mice.

\section{DAGL $\alpha$ localization in the OPL}

DAGL $\alpha$ was intensely expressed in the OPL; it was expressed in photoreceptor terminals but not in cone pedicles. Logically, these findings indicate that DAGL $\alpha$ is expressed in rod photoreceptor terminals. Moreover, we also demonstrated that DAGL $\alpha$ is expressed in the processes of horizontal cells but not in the dendritic connections of rod bipolar cells. We were unable to 


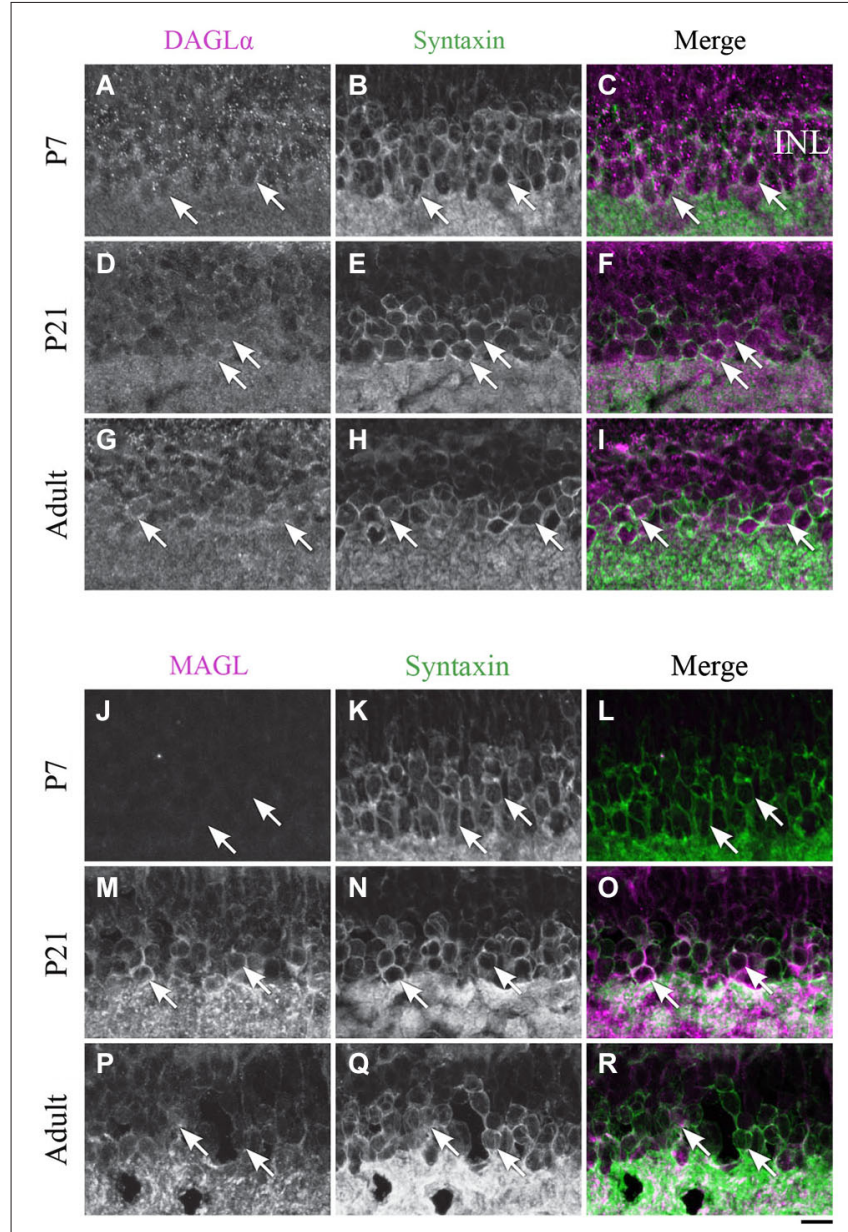

FIGURE 8 | Expression of DAGL $\alpha$ and MAGL in amacrine cells. (A-R) confocal micrographs of P7, P21 and adult rat retinas co-immunolabeled for DAGL $\alpha(\mathbf{A}-\mathbf{I})$ or MAGL (J-R) and the cell-type specific marker for the amacrine cells, syntaxin. DAGL $\alpha$ is localized in the cell bodies (arrows) of the amacrine cells from P1 to the adult age while MAGL is not detectable in these cells until P11. It is then expressed in the amacrine cells into adulthood. INL, inner nuclear layer. Scale bar $=10 \mu \mathrm{m}$.

verify the presence of DAGL $\alpha$ in the dendritic connections of cone bipolar cells. Therefore, in the OPL, DAGL $\alpha$ is present in rod photoreceptor terminals, horizontal cell processes and possibly in the dendritic connections of cone bipolar cells.

\section{DAGL $\alpha$ localization in the IPL}

DAGL $\alpha$ is also intensely expressed in the IPL. We showed that DAGL $\alpha$ was not expressed in the dendrites of amacrine or ganglion cells. We also determined that DAGL $\alpha$ was present in the axon terminals of bipolar cells, but these connections were not from type 2 or 8 cone bipolar cells or rod bipolar cells. Comparisons of the shapes and positions of DAGL $\alpha$ labeling to those of the axon terminals of type 2 and 8 cone bipolar cells, as shown in Figures 11J-L, allowed for a hypothesis about the cell types in which DAGL $\alpha$ was present. Based on Figure 8 of Ghosh et al. (2004), which shows the stratification of each type of bipolar cell in the rat retina, we propose that DAGL $\alpha$

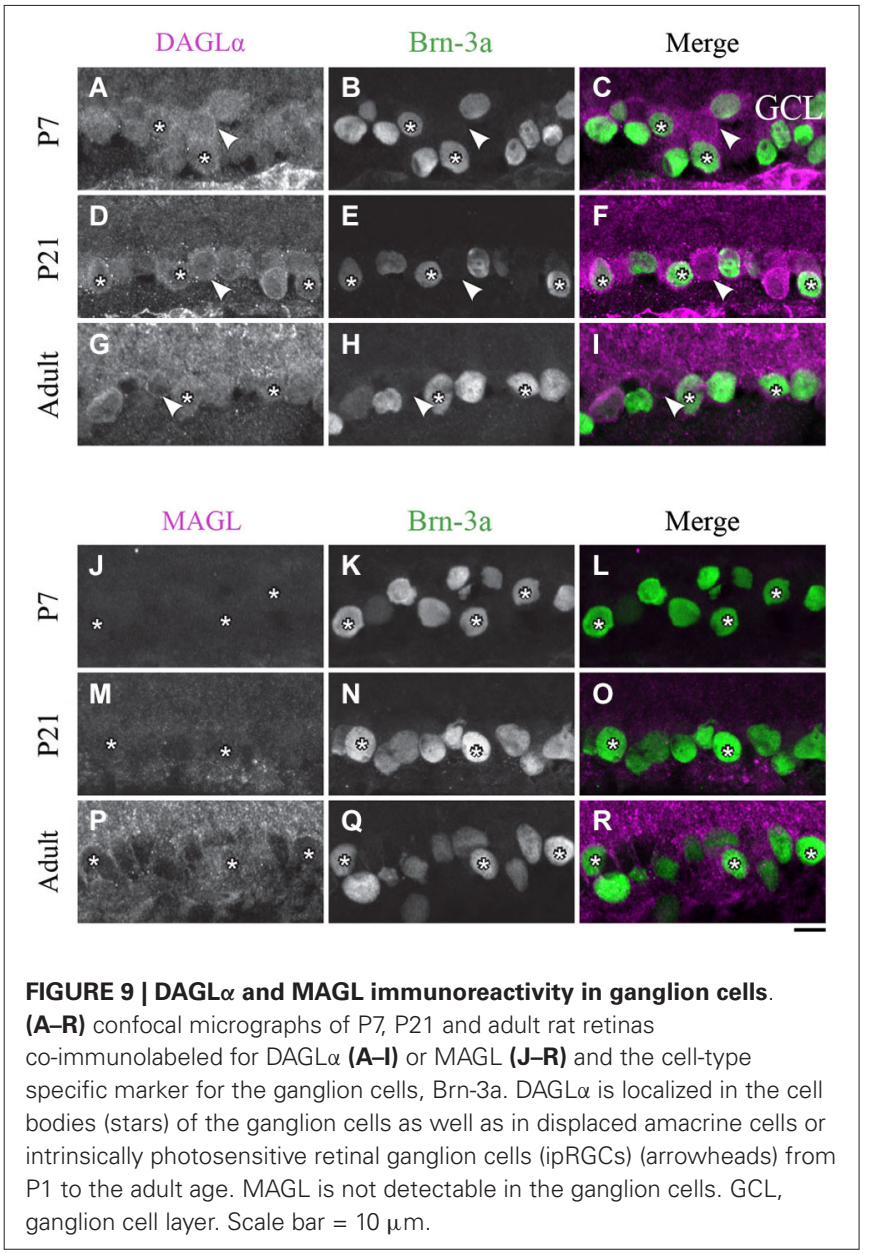

is expressed in the axon terminals of type 6 and/or 7 ON cone bipolar cells.

\section{Cellular localization of MAGL}

MAGL was minimally expressed in the retina until P11. At adulthood, MAGL was expressed in amacrine and Müller cells and in the axon terminals of type 2 cone bipolar cells. These results are, to some extent, in agreement with those of previous studies that have reported the presence of MAGL in the OPL (rod spherules and cone pedicles), IPL and GCL (Hu et al., 2010). We believe that the expression reported by Hu et al. (2010) might reflect the presence of MAGL in Müller cells. Müller cell bodies sit in the INL and project processes in either direction to the outer and inner limiting membranes. Therefore, somata or processes of these cells are present in every retinal cell layer and might be responsible for the localization of MAGL reported by $\mathrm{Hu}$ et al. (2010) in adult animals.

\section{MAGL localization in the IPL}

MAGL was also intensely expressed in the IPL. MAGL was present in the axon terminals of type 2 OFF cone bipolar cells, but not in type $8 \mathrm{ON}$ cone bipolar cells or in rod bipolar cells. However, MAGL was not restricted to type 2 cone bipolar cells. On the 


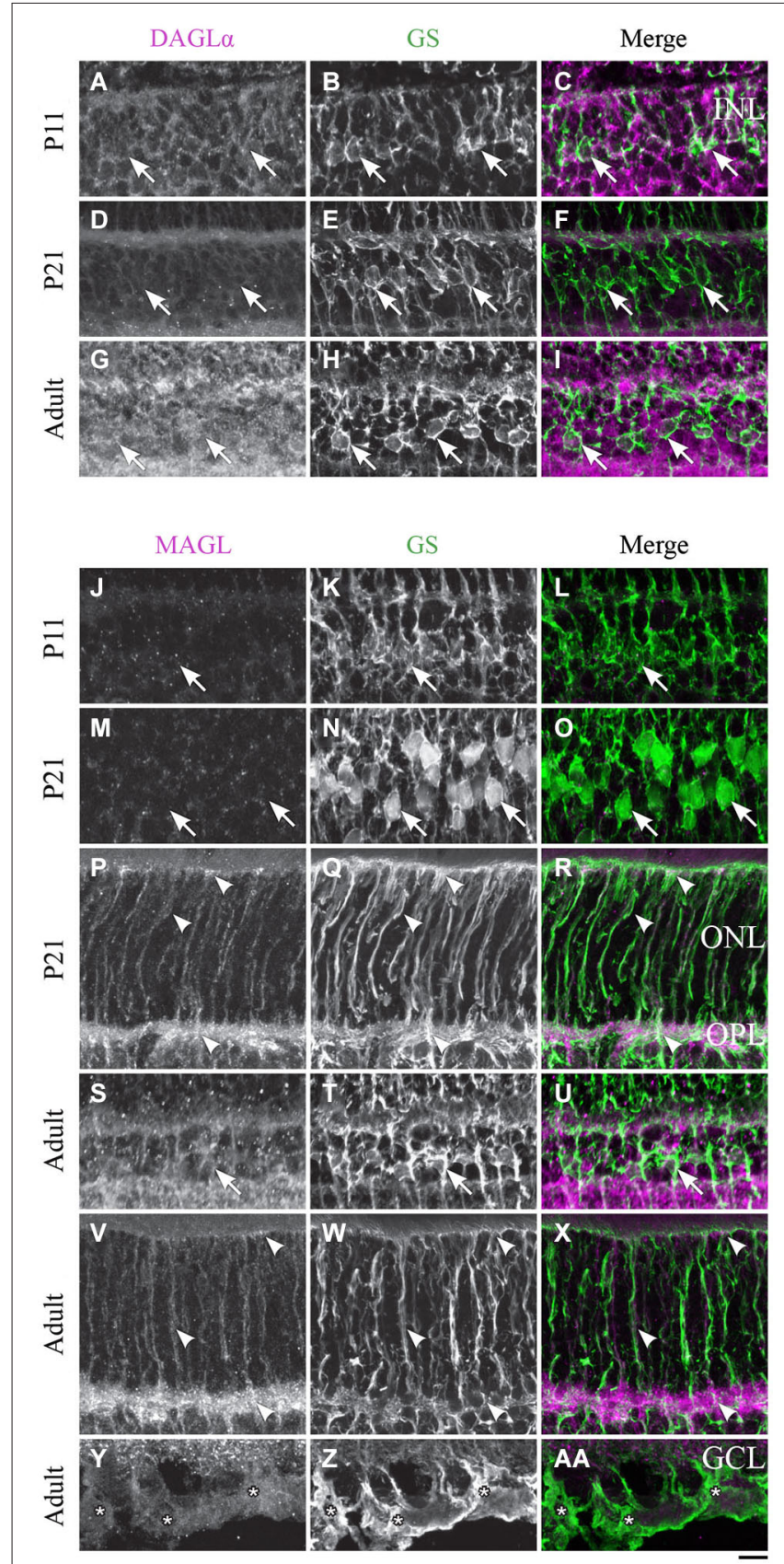

FIGURE 10 | DAGL $\alpha$ and MAGL immunoreactivity in Müller cells. (A-AA) confocal micrographs of P11, P21 and adult rat retinas co-immunolabeled for DAGL $\alpha$ (A-I) or MAGL (J-AA) and the cell-type specific marker for the Müller cells, glutamine synthetase (GS). DAGL $\alpha$ is not expressed in the cell bodies (arrows), or any part of the Müller cells. MAGL is not detectable in the cell bodies of the Müller cells (J-O, S-U) MAGL is localized in the outer (P-R, $\mathbf{V}-\mathbf{X})$ and inner (Y-AA) processes of the Müller cells from P11 to the adult age. INL, inner nuclear layer; ONL, outer nuclear layer; $\mathrm{OPL}$, outer plexiform layer; $\mathrm{GCL}$, ganglion cell layer. Scale bar $=10 \mu \mathrm{m}$

basis of the position of the MAGL expression in the IPL, we hypothesize that MAGL might be present in the axon terminals of type 3 or 4 OFF cone bipolar cells. Additionally, we showed

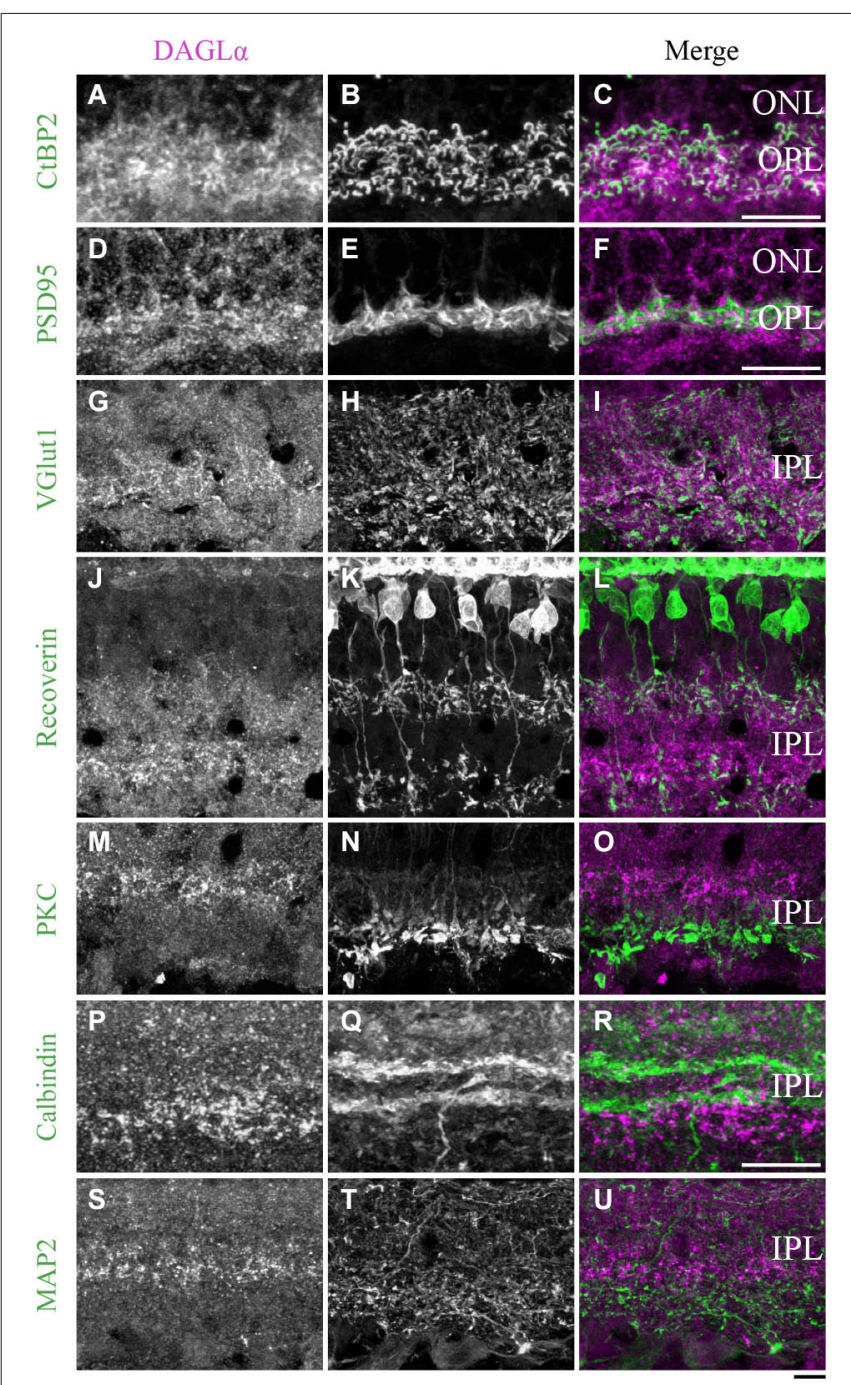

FIGURE 11 | DAGL $\alpha$ immunoreactivity in the outer and inner plexiform layers. (A-U) confocal micrographs of adult retinas co-immunolabeled for DAGL $\alpha$ and several markers for photoreceptor synaptic ribbons (CtBP2), photoreceptor terminals (PSD95), axon terminals of the bipolar cells (VGlut1), axon terminals of type 2 and 8 cone bipolar cells (recoverin), axon terminals of rod bipolar cells (PKC $\alpha$ ), dendrites of amacrine cells (calbindin) or dendrites of ganglion cells (MAP2). DAGL $\alpha$ is localized in the synaptic terminals of the photoreceptors (A-F), and in the axon terminals of the bipolar cells (G-I). However, DAGL $\alpha$ is not expressed in the axon terminals of type 2 and 8 cone bipolar cells $(\mathbf{J}-\mathbf{L})$ or rod bipolar cells $(\mathbf{M}-\mathbf{O})$. DAGL $\alpha$ is not expressed in the dendrites of amacrine (P-R) or ganglion cells (S-U). $\mathrm{ONL}$, outer nuclear layer; $\mathrm{OPL}$, outer plexiform layer; IPL, inner plexiform layer. Scale bar $=10 \mu \mathrm{m}$

that MAGL was not detectable in the dendrites of amacrine or ganglion cells.

\section{Functional considerations}

Because eCBs are lipophilic ligands that are released and degraded near their sites of action, one would predict that DAGL $\alpha$ and MAGL would have similar distributions. Obviously, DAGL $\alpha$ and MAGL do not share a similar distribution; DAGL $\alpha$ was expressed in nearly every retinal 


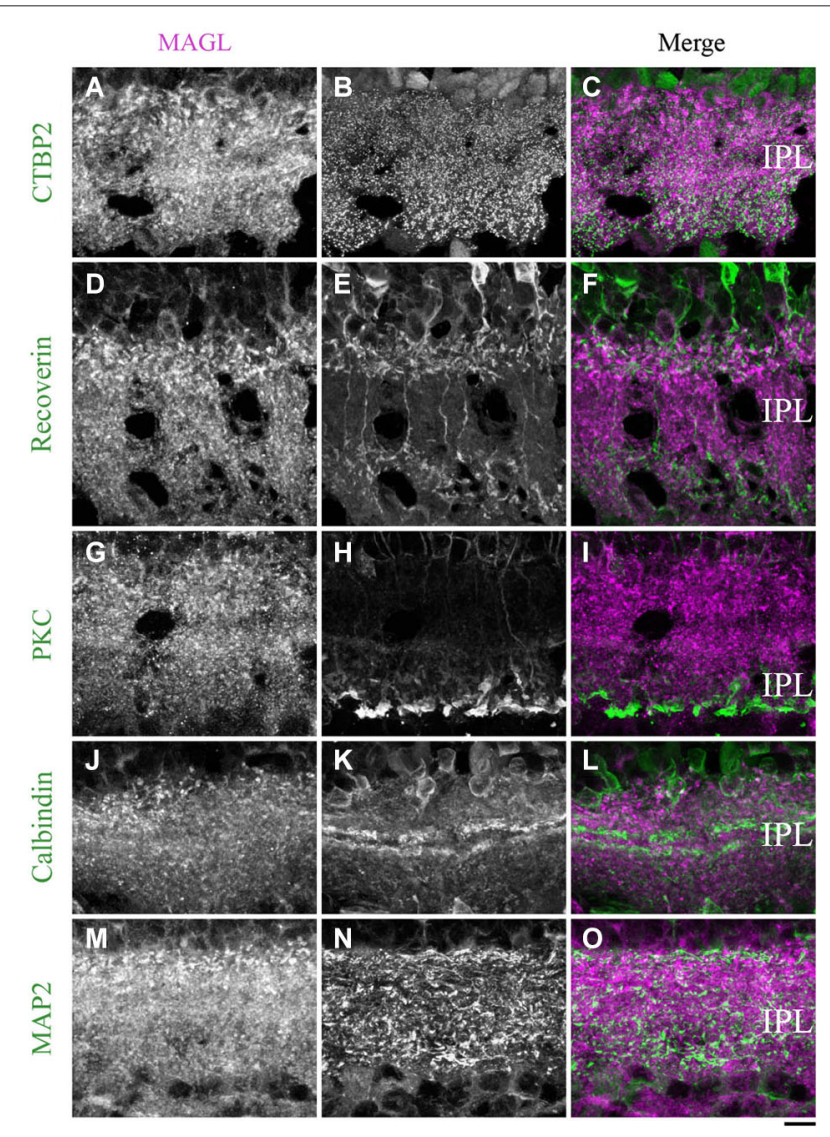

FIGURE 12 | MAGL immunoreactivity in the inner plexiform layer. (A-L) confocal micrographs of adult retinas co-immunolabeled for MAGL and several markers for axon terminals of bipolar cells (CtBP2), axon terminals of type 2 and 8 cone bipolar cells (recoverin), axon terminals of rod bipolar cells (PKC $\alpha$ ) or dendrites of ganglion cells (MAP2). MAGL is localized in the axon terminals of bipolar cells (A-C), but not in the axon terminals of type 2 and 8 cone bipolar cells (D-F) or rod bipolar cells (G-I). MAGL is not expressed in the dendrites of amacrine $\mathbf{( J - L )}$ or ganglion cells $(\mathbf{M}-\mathbf{O})$. IPL, inner plexiform layer. Scale bar $=10 \mu \mathrm{m}$.

cell type, and MAGL was only expressed in amacrine and Müller cells. However, because Müller cells stretch radially across the thickness of the retina and insinuate themselves between the cell bodies of neurons in the nuclear layers and envelop groups of neural processes in the plexiform layers, DAGL $\alpha$ and MAGL are nearly co-expressed in every retinal cell layer.

DAGL $\alpha$ and MAGL are often near or in the same cell types as $\mathrm{CB} 1 \mathrm{R}$ and $\mathrm{CB} 2 \mathrm{R}$. CB1R is present in cones, horizontal, bipolar, amacrine and ganglion cells in the developing rat retina (Zabouri et al., 2011a). CB2R is present in cone and rod photoreceptors and horizontal, bipolar, amacrine and ganglion cells in the adult mouse retina (Cécyre et al., 2013). Taken together, these results suggest that, in the retina, eCBs, such as 2-AG, are expressed closely to cannabinoid receptors and might be implicated in the regulation of the maturation of the retina. Because eCBs are known to participate in developmental processes, such as neurogenesis,
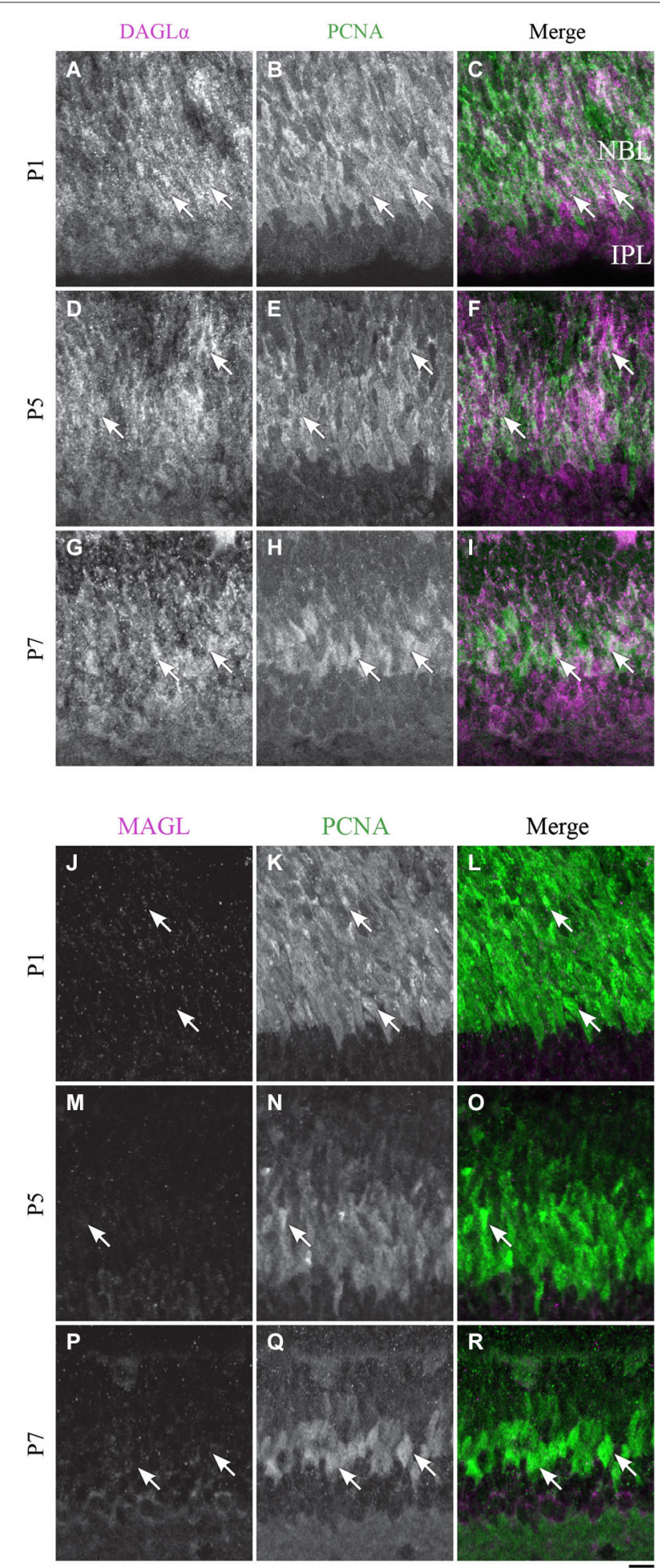

FIGURE 13 | DAGL $\alpha$ and MAGL immunoreactivity in progenitor cells. (A-R) confocal micrographs of P1, P5 and P7 rat retinas co-immunolabeled for DAGL $\alpha(\mathbf{A}-\mathbf{I})$ or MAGL (J-R) and the cell-type specific marker for the progenitor cells, PCNA. DAGL $\alpha$ is localized in the cell bodies (arrows) of progenitor cells from P1 to P7, while MAGL is not detectable in them. NBL, neuroblast layer; IPL, inner plexiform layer. Scale bar $=10 \mu \mathrm{m}$ 


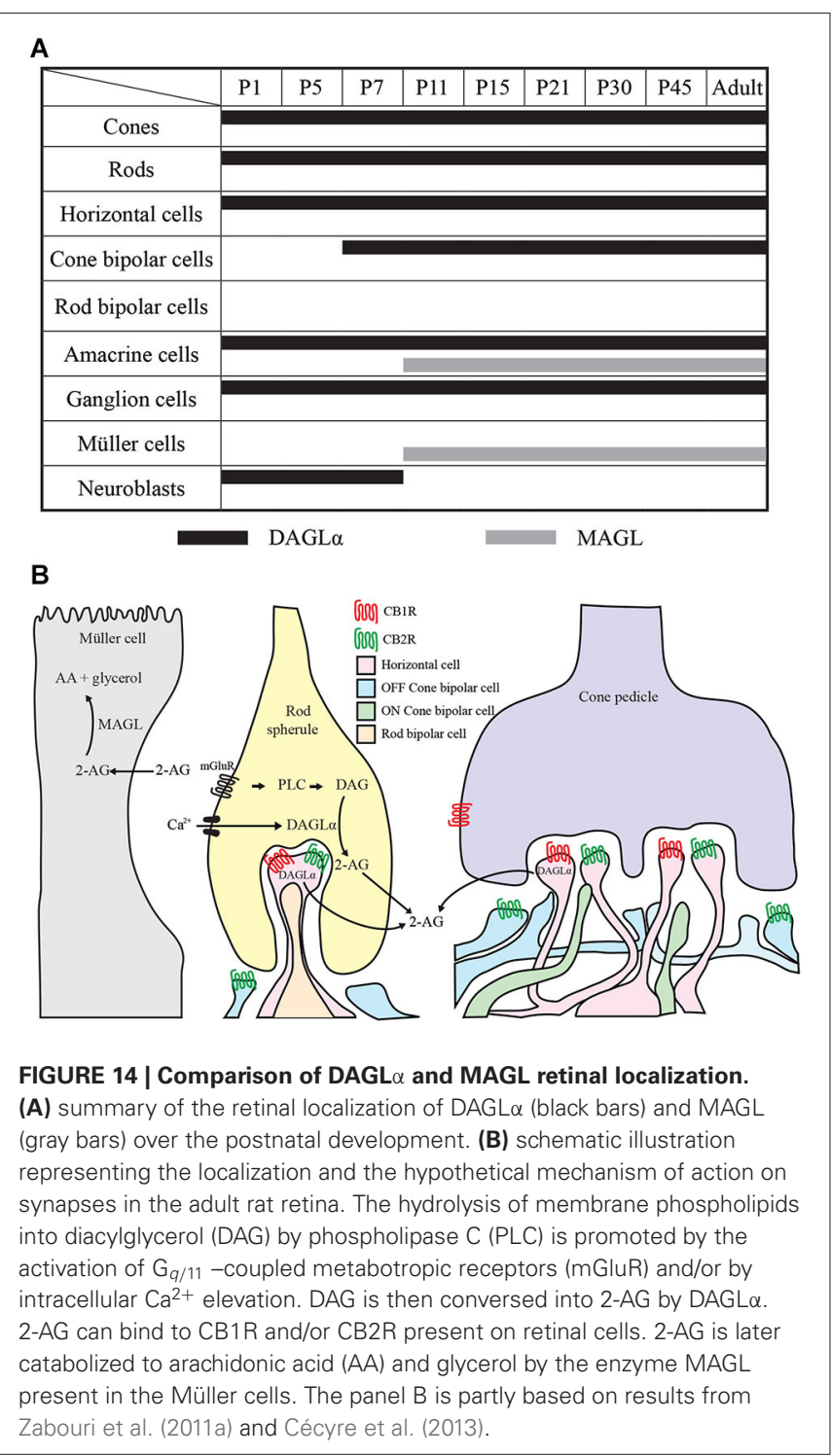

axon guidance and synaptogenesis, they might play an essential role in the structural and functional development of the retina.

The very low levels of protein content of MAGL in the retina from birth to P11 were surprising given the importance of MAGL in 2-AG hydrolysis. Because MAGL is responsible for approximately $85 \%$ of the hydrolysis of $2-A G$, it is possible that the enzymes ABHD6 and ABHD12 mediate 2-AG hydrolysis in the first days of development when MAGL is absent.

In conclusion, this study revealed the presence of DAGL $\alpha$ and MAGL in the retinal cells of developing and adult rats. We propose that retinal 2-AG levels increase from birth to P11 and are then regularized in adulthood. DAGL $\alpha$, MAGL, $\mathrm{CB} 1 \mathrm{R}$ and $\mathrm{CB} 2 \mathrm{R}$ proteins are present in young and adult animals, which suggests that the $\mathrm{eCB}$ system might play an important role in the development and function of the retina.

\section{AUTHOR CONTRIBUTIONS}

All authors had full access to all the data in the study and take responsibility for the integrity of the data and the accuracy of the data analysis. Study concept and design: Bruno Cécyre, Christian Casanova, Jean-François Bouchard. Acquisition of data: Bruno Cécyre, Marjorie Monette, Liza Beudjekian. Analysis and interpretation of data: Bruno Cécyre, Marjorie Monette, Liza Beudjekian, Christian Casanova, Jean-François Bouchard. Drafting of the manuscript: Bruno Cécyre, Christian Casanova, Jean-François Bouchard. Statistical analysis: Bruno Cécyre. Obtained funding: Christian Casanova, Jean-François Bouchard.

\section{ACKNOWLEDGMENTS}

We would like to thank the Mary D. Allen Laboratory for Vision Research, Doheny Eye Institute and Dr. Cheryl M. Craft for generously supplying the antibody against cone arrestin. We also would like to thank Sébastien Thomas, Geneviève Cyr and Florence Dotigny for their excellent assistance. This work was supported in part by a CIHR (MOP 301710) to JeanFrançois Bouchard. and Christian Casanova and by a NSERC grant (RGPIN-2014-06503) to Christian Casanova, a CIHR grant (MOP 177796) and a NSERC grant (311892-2010) to JeanFrançois Bouchard. Bruno Cécyre is supported by a studentship from Réseau Fonds de recherche du Québec-Santé (FRQ-S), a studentship from École d'optométrie et Faculté des études supérieures et postdoctorales de l'Université de Montréal, a FRQ$S$ de recherche en santé de la vision studentship. Jean-François Bouchard salary is supported in part by a Chercheur-Boursier Senior from the FRQ-S.

\section{REFERENCES}

Anavi-Goffer, S., and Mulder, J. (2009). The polarised life of the endocannabinoid system in CNS development. Chembiochem 10, 1591-1598. doi: 10.1002/cbic. 200800827

Arellano, J. I., Guadiana, S. M., Breunig, J. J., Rakic, P., and Sarkisian, M. R. (2012). Development and distribution of neuronal cilia in mouse neocortex. J. Comp. Neurol. 520, 848-873. doi: 10.1002/cne.22793

Argaw, A., Duff, G., Zabouri, N., Cécyre, B., Chainé, N., Cherif, H., et al. (2011). Concerted action of CB1 cannabinoid receptor and deleted in colorectal cancer in axon guidance. J. Neurosci. 31, 1489-1499. doi: 10.1523/jneurosci.4134-09. 2011

Barton, K. M., and Levine, E. M. (2008). Expression patterns and cell cycle profiles of PCNA, MCM6, cyclin D1, cyclin A2, cyclin B1 and phosphorylated histone H3 in the developing mouse retina. Dev. Dyn. 237, 672-682. doi: 10.1002/dvdy. 21449

Berghuis, P., Dobszay, M. B., Wang, X., Spano, S., Ledda, F., Sousa, K. M., et al. (2005). Endocannabinoids regulate interneuron migration and morphogenesis by transactivating the TrkB receptor. Proc. Natl. Acad. Sci. U S A 102, 1911519120. doi: $10.1073 /$ pnas. 0509494102

Berrendero, F., Garcìa-Gil, L., Hernández, M. L., Romero, J., Cebeira, M., de Miguel, R., et al. (1998). Localization of mRNA expression and activation of signal transduction mechanisms for cannabinoid receptor in rat brain during fetal development. Development 125, 3179-3188.

Berrendero, F., Sepe, N., Ramos, J. A., Di Marzo, V., and Fernández-Ruiz, J. J. (1999). Analysis of cannabinoid receptor binding and mRNA expression and endogenous cannabinoid contents in the developing rat brain during late gestation and early postnatal period. Synapse 33, 181-191. doi: 10.1002/(sici) 10982396(19990901)33:3<181::aid-syn3>3.0.co;2-r

Blankman, J. L., Simon, G. M., and Cravatt, B. F. (2007). A comprehensive profile of brain enzymes that hydrolyze the endocannabinoid 2-arachidonoylglycerol. Chem. Biol. 14, 1347-1356. doi: 10.1016/j.chembiol.2007.11.006 
Bobu, C., and Hicks, D. (2009). Regulation of retinal photoreceptor phagocytosis in a diurnal mammal by circadian clocks and ambient lighting. Invest. Ophthalmol. Vis. Sci. 50, 3495-3502. doi: 10.1167/iovs.08-3145

Bobu, C., Lahmam, M., Vuillez, P., Ouarour, A., and Hicks, D. (2008). Photoreceptor organisation and phenotypic characterization in retinas of two diurnal rodent species: potential use as experimental animal models for human vision research. Vision Res. 48, 424-432. doi: 10.1016/j.visres.2007. 08.011

Cécyre, B., Zabouri, N., Huppé-Gourgues, F., Bouchard, J. F., and Casanova, C. (2013). Roles of cannabinoid receptors type 1 and 2 on the retinal function of adult mice. Invest. Ophthalmol. Vis. Sci. 54, 8079-8090. doi: 10.1167/iovs.1312514

Chang, M. L., Wu, C. H., Jiang-Shieh, Y. F., Shieh, J. Y., and Wen, C. Y. (2007). Reactive changes of retinal astrocytes and Müller glial cells in kainateinduced neuroexcitotoxicity. J. Anat. 210, 54-65. doi: 10.1111/j.1469-7580.2006. 00671.x

Chun, M. H., Kim, I. B., Oh, S. J., and Chung, J. W. (1999). Synaptic connectivity of two types of recoverin-labeled cone bipolar cells and glutamic acid decarboxylase immunoreactive amacrine cells in the inner plexiform layer of the rat retina. Vis. Neurosci. 16, 791-800. doi: 10.1017/s0952523899164174

Devane, W. A., Hanus, L., Breuer, A., Pertwee, R. G., Stevenson, L. A., Griffin, G., et al. (1992). Isolation and structure of a brain constituent that binds to the cannabinoid receptor. Science 258, 1946-1949. doi: 10.1126/science.14 70919

Di Marzo, V. (2008). Targeting the endocannabinoid system: to enhance or reduce? Nat. Rev. Drug Discov. 7, 438-455. doi: 10.1038/nrd2553

Dinh, T. P., Carpenter, D., Leslie, F. M., Freund, T. F., Katona, I., Sensi, S. L., et al. (2002). Brain monoglyceride lipase participating in endocannabinoid inactivation. Proc. Natl. Acad. Sci. U S A 99, 10819-10824. doi: 10.1073/pnas. 152334899

Duff, G., Argaw, A., Cécyre, B., Cherif, H., Tea, N., Zabouri, N., et al. (2013). Cannabinoid receptor CB2 modulates axon guidance. PLoS One 8:e70849. doi: 10.1371/journal.pone.0070849

Euler, T., and Wässle, H. (1995). Immunocytochemical identification of cone bipolar cells in the rat retina. J. Comp. Neurol. 361, 461-478. doi: 10.1002/cne. 903610310

Fride, E. (2008). Multiple roles for the endocannabinoid system during the earliest stages of life: pre- and postnatal development. J. Neuroendocrinol. 20(Suppl. 1), 75-81. doi: 10.1111/j.1365-2826.2008.01670.x

Gaillard, F., Bonfield, S., Gilmour, G. S., Kuny, S., Mema, S. C., Martin, B. T., et al. (2008). Retinal anatomy and visual performance in a diurnal cone-rich laboratory rodent, the Nile grass rat (Arvicanthis niloticus). J. Comp. Neurol. 510, 525-538. doi: 10.1002/cne.21798

Galve-Roperh, I., Aguado, T., Rueda, D., Velasco, G., and Guzman, M. (2006). Endocannabinoids: a new family of lipid mediators involved in the regulation of neural cell development. Curr. Pharm. Des. 12, 2319-2325. doi: 10. 2174/138161206777585139

Gao, Y., Vasilyev, D. V., Goncalves, M. B., Howell, F. V., Hobbs, C., Reisenberg, M., et al. (2010). Loss of retrograde endocannabinoid signaling and reduced adult neurogenesis in diacylglycerol lipase knock-out mice. J. Neurosci. 30, 2017-2024. doi: 10.1523/jneurosci.5693-09.2010

Gargini, C., Terzibasi, E., Mazzoni, F., and Strettoi, E. (2007). Retinal organization in the retinal degeneration 10 (rd10) mutant mouse: a morphological and ERG study. J. Comp. Neurol. 500, 222-238. doi: 10.1002/cne.21144

Gassmann, M., Grenacher, B., Rohde, B., and Vogel, J. (2009). Quantifying Western blots: pitfalls of densitometry. Electrophoresis 30, 1845-1855. doi: 10.1002/elps. 200800720

Gerrero, M. R., McEvilly, R. J., Turner, E., Lin, C. R., O'connell, S., Jenne, K. J., et al. (1993). Brn-3.0: a POU-domain protein expressed in the sensory, immune and endocrine systems that functions on elements distinct from known octamer motifs. Proc. Natl. Acad. Sci. U S A 90, 10841-10845. doi: 10.1073/pnas.90.22. 10841

Ghosh, K. K., Bujan, S., Haverkamp, S., Feigenspan, A., and Wässle, H. (2004). Types of bipolar cells in the mouse retina. J. Comp. Neurol. 469, 70-82. doi: 10. 1002/cne.10985

Gonsiorek, W., Lunn, C., Fan, X., Narula, S., Lundell, D., and Hipkin, R. W. (2000). Endocannabinoid 2-arachidonyl glycerol is a full agonist through human type 2 cannabinoid receptor: antagonism by anandamide. Mol. Pharmacol. 57, 10451050 .
Gribaudo, S., Bovetti, S., Garzotto, D., Fasolo, A., and De Marchis, S. (2009). Expression and localization of the calmodulin-binding protein neurogranin in the adult mouse olfactory bulb. J. Comp. Neurol. 517, 683-694. doi: 10.1002/cne. 22177

Günhan, E., van der List, D., and Chalupa, L. M. (2003). Ectopic photoreceptors and cone bipolar cells in the developing and mature retina. J. Neurosci. 23, 13831389.

Guzmán, M., Sánchez, C., and Galve-Roperh, I. (2001). Control of the cell survival/death decision by cannabinoids. J. Mol. Med. (Berl) 78, 613-625. doi: 10 . 1007/s001090000177

Harkany, T., Guzmán, M., Galve-Roperh, I., Berghuis, P., Devi, L. A., and Mackie, K. (2007). The emerging functions of endocannabinoid signaling during CNS development. Trends Pharmacol. Sci. 28, 83-92. doi: 10.1016/j.tips.2006. 12.004

Haverkamp, S., and Wässle, H. (2000). Immunocytochemical analysis of the mouse retina. J. Comp. Neurol. 424, 1-23. doi: 10.1002/10969861(20000814)424:1<1::aid-cne1>3.0.co;2-v

Hendrickson, A., Troilo, D., Djajadi, H., Possin, D., and Springer, A. (2009). Expression of synaptic and phototransduction markers during photoreceptor development in the marmoset monkey Callithrix jacchus. J. Comp. Neurol. 512, 218-231. doi: 10.1002/cne.21893

Herkenham, M., Lynn, A. B., Johnson, M. R., Melvin, L. S., De Costa, B. R., and Rice, K. C. (1991). Characterization and localization of cannabinoid receptors in rat brain: a quantitative in vitro autoradiographic study. J. Neurosci. 11, 563583.

Hirano, A. A., Brandstätter, J. H., and Brecha, N. C. (2005). Cellular distribution and subcellular localization of molecular components of vesicular transmitter release in horizontal cells of rabbit retina. J. Comp. Neurol. 488, 70-81. doi: 10. 1002/cne.20577

Hirano, A. A., Brandstätter, J. H., Morgans, C. W., and Brecha, N. C. (2011). SNAP25 expression in mammalian retinal horizontal cells. J. Comp. Neurol. 519, 972-988. doi: 10.1002/cne.22562

Hu, S. S., Arnold, A., Hutchens, J. M., Radicke, J., Cravatt, B. F., Wager-Miller, J., et al. (2010). Architecture of cannabinoid signaling in mouse retina. J. Comp. Neurol. 518, 3848-3866. doi: 10.1002/cne.22429

Ino, H., and Chiba, T. (2000). Expression of proliferating cell nuclear antigen (PCNA) in the adult and developing mouse nervous system. Brain Res. Mol. Brain Res. 78, 163-174. doi: 10.1016/s0169-328x(00)00092-9

Inoue, A., Obata, K., and Akagawa, K. (1992). Cloning and sequence analysis of cDNA for a neuronal cell membrane antigen, HPC-1. J. Biol. Chem. 267, 1061310619.

Jain, V., Ravindran, E., and Dhingra, N. K. (2012). Differential expression of Brn3 transcription factors in intrinsically photosensitive retinal ganglion cells in mouse. J. Comp. Neurol. 520, 742-755. doi: 10.1002/cne.22765

Járai, Z., Wagner, J. A., Goparaju, S. K., Wang, L., Razdan, R. K., Sugiura, T., et al. (2000). Cardiovascular effects of 2-arachidonoyl glycerol in anesthetized mice. Hypertension 35, 679-684. doi: 10.1161/01.hyp.35.2.679

Johansson, K., Bruun, A., Devente, J., and Ehinger, B. (2000). Immunohistochemical analysis of the developing inner plexiform layer in postnatal rat retina. Invest. Ophthalmol. Vis. Sci. 41, 305-313.

Johnson, J., Fremeau, R. T. Jr., Duncan, J. L., Renteria, R. C., Yang, H., Hua, Z., et al. (2007). Vesicular glutamate transporter 1 is required for photoreceptor synaptic signaling but not for intrinsic visual functions. J. Neurosci. 27, 72457255. doi: 10.1523/jneurosci.0815-07.2007

Katona, I., and Freund, T. F. (2008). Endocannabinoid signaling as a synaptic circuit breaker in neurological disease. Nat. Med. 14, 923-930. doi: 10.1038/nm.f.1869

Kim, D. S., Ross, S. E., Trimarchi, J. M., Aach, J., Greenberg, M. E., and Cepko, C. L. (2008). Identification of molecular markers of bipolar cells in the murine retina. J. Comp. Neurol. 507, 1795-1810. doi: 10.1002/cne.21639

Koulen, P., Fletcher, E. L., Craven, S. E., Bredt, D. S., and Wässle, H. (1998). Immunocytochemical localization of the postsynaptic density protein PSD-95 in the mammalian retina. J. Neurosci. 18, 10136-10149.

Kreitzer, A. C., and Regehr, W. G. (2001). Cerebellar depolarization-induced suppression of inhibition is mediated by endogenous cannabinoids. J. Neurosci. 21, RC174.

Kunzevitzky, N. J., Willeford, K. T., Feuer, W. J., Almeida, M. V., and Goldberg, J. L. (2013). Amacrine cell subtypes differ in their intrinsic neurite growth capacity. Invest. Ophthalmol. Vis. Sci. 54, 7603-7613. doi: 10.1167/iovs.1312691 
Lalonde, M. R., Jollimore, C. A., Stevens, K., Barnes, S., and Kelly, M. E. (2006). Cannabinoid receptor-mediated inhibition of calcium signaling in rat retinal ganglion cells. Mol. Vis. 12, 1160-1166.

Li, S., Mo, Z., Yang, X., Price, S. M., Shen, M. M., and Xiang, M. (2004). Foxn4controls the genesis of amacrine and horizontal cells by retinal progenitors. Neuron 43, 795-807. doi: 0.1016/j.neuron.2004.08.041

Li, Y., Zheng, H., Liu, P. P., Chen, Y. Y., She, Z. J., Xiao, H. L., et al. (2010). The new targets of ouabain in retinal interneurons of Sprague-Dawley rats. Brain Res. Bull. 81, 617-624. doi: 10.1016/j.brainresbull.2010.01.012

Li, C., Zhou, Y., Liu, Z., Tuo, J., Hu, N., and Guan, H. (2012). Spatiotemporal expression of postsynaptic density 95 in rat retina after optic nerve injury. $J$. Mol. Neurosci. 46, 595-605. doi: 10.1007/s12031-011-9647-7

Luisier, F., and Blu, T. (2008). SURE-LET multichannel image denoising: interscale orthonormal wavelet thresholding. IEEE Trans. Image Process. 17, 482-492. doi: 10.1109/TIP.2008.919370

Mackie, K., Devane, W. A., and Hille, B. (1993). Anandamide, an endogenous cannabinoid, inhibits calcium currents as a partial agonist in N18 neuroblastoma cells. Mol. Pharmacol. 44, 498-503.

Massey, S. C., and Mills, S. L. (1996). A calbindin-immunoreactive cone bipolar cell type in the rabbit retina. J. Comp. Neurol. 366, 15-33. doi: 10.1002/(sici)10969861(19960226)366:1<15::aid-cne2>3.0.co;2-n

Matsuoka, R. L., Nguyen-Ba-Charvet, K. T., Parray, A., Badea, T. C., Chédotal, A., and Kolodkin, A. L. (2011). Transmembrane semaphorin signalling controls laminar stratification in the mammalian retina. Nature 470, 259-263. doi: 10. 1038/nature09675

Milam, A. H., Dacey, D. M., and Dizhoor, A. M. (1993). Recoverin immunoreactivity in mammalian cone bipolar cells. Vis. Neurosci. 10, 1-12. doi: 10 . 1017/s0952523800003175

Mitchell, C. K., Rowe-Rendleman, C. L., Ashraf, S., and Redburn, D. A. (1995). Calbindin immunoreactivity of horizontal cells in the developing rabbit retina. Exp. Eye Res. 61, 691-698. doi: 10.1016/s0014-4835(05)80020-x

Mojumder, D. K., Wensel, T. G., and Frishman, L. J. (2008). Subcellular compartmentalization of two calcium binding proteins, calretinin and calbindin-28 kDa, in ganglion and amacrine cells of the rat retina. Mol. Vis. 14, 1600-1613.

Morgan, J. L., Dhingra, A., Vardi, N., and Wong, R. O. (2006). Axons and dendrites originate from neuroepithelial-like processes of retinal bipolar cells. Nat. Neurosci. 9, 85-92. doi: 10.1038/nn1615

Nadal-Nicolás, F. M., Jiménez-López, M., Sobrado-Calvo, P., Nieto-López, L., Cánovas-Martínez, I., Salinas-Navarro, M., et al. (2009). Brn3a as a marker of retinal ganglion cells: qualitative and quantitative time course studies in naive and optic nerve-injured retinas. Invest. Ophthalmol. Vis. Sci. 50, 3860-3868. doi: 10.1167/iovs.08-3267

Nagar, S., Krishnamoorthy, V., Cherukuri, P., Jain, V., and Dhingra, N. K. (2009). Early remodeling in an inducible animal model of retinal degeneration. Neuroscience 160, 517-529. doi: 10.1016/j.neuroscience.2009.02.056

Nakajima, M., Cooney, M. J., Tu, A. H., Chang, K. Y., Cao, J., Ando, A., et al. (2001). Normalization of retinal vascular permeability in experimental diabetes with genistein. Invest. Ophthalmol. Vis. Sci. 42, 2110-2114.

Negishi, K., Kato, S., and Teranishi, T. (1988). Dopamine cells and rod bipolar cells contain protein kinase C-like immunoreactivity in some vertebrate retinas. Neurosci. Lett. 94, 247-252. doi: 10.1016/0304-3940(88) 90025-0

Nikonov, S. S., Brown, B. M., Davis, J. A., Zuniga, F. I., Bragin, A., Pugh, E. N., et al. (2008). Mouse cones require an arrestin for normal inactivation of phototransduction. Neuron 59, 462-474. doi: 10.1016/j.neuron.2008. 06.011

Okabe, S., Shiomura, Y., and Hirokawa, N. (1989). Immunocytochemical localization of microtubule-associated proteins $1 \mathrm{~A}$ and 2 in the rat retina. Brain Res. 483, 335-346. doi: 10.1016/0006-8993(89)90178-9

Østergaard, J., Hannibal, J., and Fahrenkrug, J. (2007). Synaptic contact between melanopsin-containing retinal ganglion cells and rod bipolar cells. Invest. Ophthalmol. Vis. Sci. 48, 3812-3820. doi: 10.1167/iovs.06-1322

Oudin, M. J., Gajendra, S., Williams, G., Hobbs, C., Lalli, G., and Doherty, P. (2011). Endocannabinoids regulate the migration of subventricular zonederived neuroblasts in the postnatal brain. J. Neurosci. 31, 4000-4011. doi: 10. 1523/JNEUROSCI.5483-10.2011

Pasteels, B., Rogers, J., Blachier, F., and Pochet, R. (1990). Calbindin and calretinin localization in retina from different species. Vis. Neurosci. 5, 1-16. doi: 10. $1017 / \mathrm{s} 0952523800000031$
Peichl, L., and González-Soriano, J. (1994). Morphological types of horizontal cell in rodent retinae: a comparison of rat, mouse, gerbil and guinea pig. Vis. Neurosci. 11, 501-517. doi: 10.1017/s095252380000242x

Pellegrini, E., Mouriec, K., Anglade, I., Menuet, A., Le Page, Y., Gueguen, M. M., et al. (2007). Identification of aromatase-positive radial glial cells as progenitor cells in the ventricular layer of the forebrain in zebrafish. J. Comp. Neurol. 501, 150-167. doi: 10.1002/cne.21222

Pertwee, R., Howlett, A., Abood, M., Alexander, S., Di Marzo, V., Elphick, M., et al. (2010). International Union of basic and clinical pharmacology. LXXIX. Cannabinoid receptors and their ligands: beyond $\mathrm{CB}_{1}$ and $\mathrm{CB}_{2}$. Pharmacol. Rev. 62, 588-631. doi: 10.1124/pr.110.003004

Rapaport, D. H., Wong, L. L., Wood, E. D., Yasumura, D., and LaVail, M. M. (2004). Timing and topography of cell genesis in the rat retina. J. Comp. Neurol. 474, 304-324. doi: 10.1002/cne.20134

Rivera, P., Arrabal, S., Vargas, A., Blanco, E., Serrano, A., Pavón, F. J., et al. (2014). Localization of peroxisome proliferator-activated receptor alpha (PPARalpha) and $\mathrm{N}$-acyl phosphatidylethanolamine phospholipase D (NAPE-PLD) in cells expressing the $\mathrm{Ca}(2+)$-binding proteins calbindin, calretinin and parvalbumin in the adult rat hippocampus. Front. Neuroanat. 8:12. doi: 10.3389/fnana.2014. 00012

Savinainen, J. R., Järvinen, T., Laine, K., and Laitinen, J. T. (2001). Despite substantial degradation, 2-arachidonoylglycerol is a potent full efficacy agonist mediating $\mathrm{CB}(1)$ receptor-dependent G-protein activation in rat cerebellar membranes. Br. J. Pharmacol. 134, 664-672. doi: 10.1038/sj.bjp.07 04297

Schindelin, J., Arganda-Carreras, I., Frise, E., Kaynig, V., Longair, M., Pietzsch, T., et al. (2012). Fiji: an open-source platform for biological-image analysis. Nat. Methods 9, 676-682. doi: 10.1038/nmeth.2019

Schneider, C. A., Rasband, W. S., and Eliceiri, K. W. (2012). NIH Image to ImageJ: 25 years of image analysis. Nat. Methods 9, 671-675. doi: 10.1038/nmeth.2089

Seki, M., Nawa, H., Fukuchi, T., Abe, H., and Takei, N. (2003). BDNF is upregulated by postnatal development and visual experience: quantitative and immunohistochemical analyses of BDNF in the rat retina. Invest. Ophthalmol. Vis. Sci. 44, 3211-3218. doi: 10.1167/iovs.02-1089

Sherry, D. M., Wang, M. M., Bates, J., and Frishman, L. J. (2003). Expression of vesicular glutamate transporter 1 in the mouse retina reveals temporal ordering in development of rod vs. cone and ON vs. OFF circuits. J. Comp. Neurol. 465, 480-498. doi: 10.1002/cne.10838

Sjöström, P. J., Turrigiano, G. G., and Nelson, S. B. (2003). Neocortical LTD via coincident activation of presynaptic NMDA and cannabinoid receptors. Neuron 39, 641-654. doi: 10.1016/s0896-6273(03)00476-8

Stella, S. L. Jr. Li, S., Sabatini, A., Vila, A., and Brecha, N. C. (2008). Comparison of the ontogeny of the vesicular glutamate transporter 3 (VGLUT3) with VGLUT1 and VGLUT2 in the rat retina. Brain Res. 1215, 20-29. doi: 10.1016/j.brainres. 2008.03.038

Stella, N., Schweitzer, P., and Piomelli, D. (1997). A second endogenous cannabinoid that modulates long-term potentiation. Nature 388, 773-778. doi: 10 . $1038 / 42015$

Suárez, J., Bermúdez-Silva, F. J., Mackie, K., Ledent, C., Zimmer, A., Cravatt, B. F., et al. (2008). Immunohistochemical description of the endogenous cannabinoid system in the rat cerebellum and functionally related nuclei. J. Comp. Neurol. 509, 400-421. doi: 10.1002/cne.21774

Sugiura, T., Kishimoto, S., Oka, S., and Gokoh, M. (2006). Biochemistry, pharmacology and physiology of 2-arachidonoylglycerol, an endogenous cannabinoid receptor ligand. Prog. Lipid Res. 45, 405-446. doi: 10.1016/j.plipres.2006. 03.003

Sugiura, T., Kondo, S., Sukagawa, A., Nakane, S., Shinoda, A., Itoh, K., et al. (1995). 2-Arachidonoylglycerol: a possible endogenous cannabinoid receptor ligand in brain. Biochem. Biophys. Res. Commun. 215, 89-97. doi: 10.1006/bbrc.1995. 2437

Suzuki, O., Koura, M., Noguchi, Y., Uchio-Yamada, K., and Matsuda, J. (2011). Use of sample mixtures for standard curve creation in quantitative western blots. Exp. Anim. 60, 193-196. doi: 10.1538/expanim.60.193

Takamori, S., Rhee, J. S., Rosenmund, C., and Jahn, R. (2000). Identification of a vesicular glutamate transporter that defines a glutamatergic phenotype in neurons. Nature 407, 189-194. doi: 10.1038/35025070

Tan, H. Y., and Ng, T. W. (2008). Accurate step wedge calibration for densitometry of electrophoresis gels. Opt. Commun. 281, 3013-3017. doi: 10.1016/j.optcom. 2008.01.012 
Tanimura, A., Yamazaki, M., Hashimotodani, Y., Uchigashima, M., Kawata, S., Abe, M., et al. (2010). The endocannabinoid 2-arachidonoylglycerol produced by diacylglycerol lipase alpha mediates retrograde suppression of synaptic transmission. Neuron 65, 320-327. doi: 10.1016/j.neuron.2010.01.021

tom Dieck, S., Altrock, W. D., Kessels, M. M., Qualmann, B., Regus, H., Brauner, D., et al. (2005). Molecular dissection of the photoreceptor ribbon synapse: physical interaction of Bassoon and RIBEYE is essential for the assembly of the ribbon complex. J. Cell Biol. 168, 825-836. doi: 10.1083/jcb.200408157

Uchigashima, M., Yamazaki, M., Yamasaki, M., Tanimura, A., Sakimura, K., Kano, M., et al. (2011). Molecular and morphological configuration for 2arachidonoylglycerol-mediated retrograde signaling at mossy cell-granule cell synapses in the dentate gyrus. J. Neurosci. 31, 7700-7714. doi: 10.1523/jneurosci. 5665-10.2011

Voinescu, P. E., Kay, J. N., and Sanes, J. R. (2009). Birthdays of retinal amacrine cell subtypes are systematically related to their molecular identity and soma position. J. Comp. Neurol. 517, 737-750. doi: 10.1002/cne.22200

Warrier, A., and Wilson, M. (2007). Endocannabinoid signaling regulates spontaneous transmitter release from embryonic retinal amacrine cells. Vis. Neurosci. 24, 25-35. doi: 10.1017/s0952523807230160

Waseem, N. H., and Lane, D. P. (1990). Monoclonal antibody analysis of the proliferating cell nuclear antigen (PCNA). Structural conservation and the detection of a nucleolar form. J. Cell Sci. 96(Pt. 1), 121-129.

Wilson, R. I., and Nicoll, R. A. (2001). Endogenous cannabinoids mediate retrograde signalling at hippocampal synapses. Nature 410, 588-592. doi: 10 . 1038/35069076

Xiang, M., Zhou, L., Macke, J. P., Yoshioka, T., Hendry, S. H., Eddy, R. L., et al. (1995). The Brn-3 family of POU-domain factors: primary structure, binding specificity and expression in subsets of retinal ganglion cells and somatosensory neurons. J. Neurosci. 15, 4762-4785.

Yazulla, S. (2008). Endocannabinoids in the retina: from marijuana to neuroprotection. Prog. Retin. Eye Res. 27, 501-526. doi: 10.1016/j.preteyeres.2008.07.002

Yoshida, T., Fukaya, M., Uchigashima, M., Miura, E., Kamiya, H., Kano, M., et al. (2006). Localization of diacylglycerol lipase-alpha around postsynaptic spine suggests close proximity between production site of an endocannabinoid, 2-arachidonoyl-glycerol and presynaptic cannabinoid CB1 receptor. J. Neurosci. 26, 4740-4751. doi: 10.1523/jneurosci.0054-06.2006

Zabouri, N., Bouchard, J. F., and Casanova, C. (2011a). Cannabinoid receptor type 1 expression during postnatal development of the rat retina. J. Comp. Neurol. 519, 1258-1280. doi: 10.1002/cne.22534

Zabouri, N., Ptito, M., Casanova, C., and Bouchard, J. F. (2011b). Fatty acid amide hydrolase expression during retinal postnatal development in rats. Neuroscience 195, 145-165. doi: 10.1016/j.neuroscience.2011.08.008

Zhu, X., Brown, B., Li, A., Mears, A. J., Swaroop, A., and Craft, C. M. (2003). GRK1dependent phosphorylation of $\mathrm{S}$ and $\mathrm{M}$ opsins and their binding to cone arrestin during cone phototransduction in the mouse retina. J. Neurosci. 23, 6152-6160.

Zhu, X., Li, A., Brown, B., Weiss, E. R., Osawa, S., and Craft, C. M. (2002). Mouse cone arrestin expression pattern: light induced translocation in cone photoreceptors. Mol. Vis. 8, 462-471.

Conflict of Interest Statement: The authors declare that the research was conducted in the absence of any commercial or financial relationships that could be construed as a potential conflict of interest.

Received: 24 July 2014; accepted: 22 November 2014; published online: 15 December 2014.

Citation: Cécyre B, Monette M, Beudjekian L, Casanova C and Bouchard $J-F$ (2014) Localization of diacylglycerol lipase alpha and monoacylglycerol lipase during postnatal development of the rat retina. Front. Neuroanat. 8:150. doi: $10.3389 /$ fnana.2014.00150

This article was submitted to the journal Frontiers in Neuroanatomy.

Copyright (C) 2014 Cécyre, Monette, Beudjekian, Casanova and Bouchard. This is an open-access article distributed under the terms of the Creative Commons Attribution License (CC BY). The use, distribution and reproduction in other forums is permitted, provided the original author(s) or licensor are credited and that the original publication in this journal is cited, in accordance with accepted academic practice. No use, distribution or reproduction is permitted which does not comply with these terms. 